\title{
Effect of Bitis gabonica and Dendroaspis angusticeps snake venoms on apoptosis- related genes in human thymic epithelial cells
}

\author{
Francisc Boda ${ }^{1}$ (), Krisztina Banfai ${ }^{2,3}$, Kitti Garai ${ }^{2,3}$, Bela Kovacsi* ${ }^{1 *}$, Attila Almasi ${ }^{4}$, Dalma Scheffer ${ }^{3,5}$, \\ Reka Lambertne Sinkler ${ }^{3,5}$, Robert Csonka ${ }^{3,5}$, Tamas Czompoly ${ }^{3,5}$, Krisztian Kvell2,3 (1) \\ ${ }^{1}$ Department F1, Faculty of Pharmacy, George Emil Palade University of Medicine, Pharmacy, Science, and Technology of Targu Mures, Targu Mures, Romania. \\ ${ }^{2}$ Department of Pharmaceutical Biotechnology, Faculty of Pharmacy, University of Pecs, Pecs, Hungary. \\ ${ }^{3}$ Food Biotechnology Research Group, Szentagothai Research Center, University of Pecs, Pecs, Hungary. \\ ${ }^{4}$ Department of Pharmaceutical Chemistry, Faculty of Pharmacy, University of Pecs, Pecs, Hungary. \\ ${ }^{5}$ Soft Flow Ltd., Pecs, Hungary.
}

\section{Keywords:}

Snake venoms

Bitis gabonica

Dendroaspis angusticeps

Apoptosis

Pyroptosis

Apoptosis mediators

RT-qPCR

Taqman array

\begin{abstract}
Background: Certain environmental toxins permanently damage the thymic epithelium, accelerate immune senescence and trigger secondary immune pathologies. However, the exact underlying cellular mechanisms and pathways of permanent immune intoxication remain unknown. The aim of the present study was to demonstrate gene expressional changes of apoptosis-related cellular pathways in human thymic epithelial cells following exposure to snake venom from Bitis gabonica and Dendroaspis angusticeps.

Methods: Snake venoms were characterized by analytical methods including reversed phase high-performance liquid chromatography and sodium dodecyl sulphatepolyacrylamide gel electrophoresis, then applied on human thymic epithelial cells (1889c) for $24 \mathrm{~h}$ at $10 \mu \mathrm{g} / \mathrm{mL}$ (as used in previous TaqMan Array study). Gene expressional changes restricted to apoptosis were assayed by TaqMan Array (Human Apoptosis Plate). Results: The most prominent gene expressional changes were shown by CASP5 $(\approx 2.5$ million-fold, confirmed by dedicated quantitative polymerase chain reaction) and CARD9 (0.016-fold) for B. gabonica, and BIRC7 (6.46-fold) and CASP1 (0.30-fold) for D. angusticeps.

Conclusion: The observed apoptotic environment suggests that pyroptosis may be the dominant pathway through which B. gabonica and D. angusticeps snake venoms trigger thymic epithelial apoptosis following envenomation.
\end{abstract}

* Correspondence: bela.kovacs@umfst.ro https://doi.org/10.1590/1678-9199-JVATITD-2020-0057

Received: 18 April 2020; Accepted: 23 September 2020; Published online: 14 December 2020 


\section{Background}

Programmed cell death (PCD) represents an intracellular mechanism that leads to the death of cells through various pathways. PCD can be triggered by external factors, such as toxins, viruses or chemical agents, but also drives differentiation and developmental processes including regulation of cell number, deletion of unnecessary cell structures and elimination of dangerous cells. The three main forms of PCD are apoptosis, autophagy and programmed necrosis [1,2].

The cytotoxic and pro-apoptotic effect of snake venoms has been extensively studied due to the possible application of venom-derived components as anti-cancer agents [3-5]. The pro-apoptotic effect has been studied from venoms of numerous genera, such as Bitis [6], Bothrops [7-10], Cerastes [6,11], Echis [12], Lachesis [13], Ophiophagus [14], Naja [15,16] and Walterinessia [17]. Furthermore, the apoptosis inducing effect of individual components isolated from snake venoms has also been studied, demonstrating that L-amino acid oxidases (LAAO) [18-20], snake venom metalloproteinases (SVMP) $[21,22]$, disintegrins $[23,24]$ and phospholipases $A_{2}\left(P_{2} A_{2}\right)[9,25]$ are capable of inducing apoptosis in various cell types. Although the apoptotic effect of snake venoms and their components are well characterized, there are still few reports on how these venoms affect other PCD mechanisms. Spermine, a polyamine isolated from the venom of Eristicophis macmahonii is capable of inducing autophagy in Trypanosoma brucei, demonstrated by the presence of autophagy vesicles and dilated mitochondria [26]. A recently published study reported that cytotoxin 1 , a polypeptide isolated from Naja atra venom increases lysosome membrane permeability and the release of cathepsin B, meaning that this molecule likely induces necroptosis in leukemia cells [27]. Furthermore, the venom of the European honey bee (Apis mellifera) has been associated with increased caspase- 1 and inflammasome activity [28], suggesting a possible induction of pyroptosis in treated cells. These observations suggest that animal venoms, including snake venoms are capable of inducing PCD through both apoptotic and non-apoptotic mechanisms.

Immune senescence, and within that thymic ageing develops in every person, although at individual rate. Thymic senescence is observed as adipose involution during which the thymus shrinks and functional epithelial network is replaced by adipose tissue [29]. Thymic ageing initiates during childhood to speed up during adolescence [30]. This process drastically impairs the production of naive T cells, cutting it by $90 \%$ by the age of 50 years in human, contributing to increased occurrence of infection, cancer and auto-immunity at senior ages [31-33]. Specific external factors may accelerate thymic senescence. Examples include chemicals (copper-chelators), hormones (androgens), infections (viruses, fungi, protozoa) and potentially biological toxins (e.g. snake venoms) [34-38]. Thymic senescence research will help to understand the underlying molecular- and cellular mechanisms and appoint new therapeutic targets for intervention strategies. Such interventions may slow down thymus senescence and enhance $\mathrm{T}$ cell production. This would in turn decrease the incidence of infection, cancer and auto-immunity that currently affects the senior population. In addition, gain in healthcare costs and quality of life share tremendous economic and social interest.

Our study aimed to determine the effect of Bitis gabonica $(B G)$ and Dendroaspis angusticeps $(D A)$ venoms on a set of apoptosisrelated genes using TaqMan Array technology in human thymic epithelial cells. Considering that these venoms originate from two different families of venomous snakes (Viperidae and Elapidae), a secondary objective was to evaluate similarities and differences concerning the effects of these venoms. Finally, based on our results, we proposed to highlight the possible longterm effect of envenomation at the cellular level with respect to thymic epithelial cells. Biological toxins (e.g. snake venoms) may trigger long-lasting alterations in the central immune system (thymus) through apoptotic pathways, thus accelerating immune senescence, with significant defects in health.

\section{Methods}

\section{Snake venoms}

Lyophilized $B G$ and $D A$ venoms were obtained from commercial sources (Latoxan S.A.S., Portes-les-Valence, France). Stock solutions were prepared by dissolving the lyophilized snake venoms in sterile phosphate buffered saline (PBS) (GE Healthcare Life Sciences, Chicago, IL, USA) at a final concentration of 10 $\mathrm{mg} / \mathrm{mL}$. Serial stock solutions were further diluted with sterile PBS to obtain the work solutions at concentrations of 30,100 , 300 and $1000 \mu \mathrm{g} / \mathrm{mL}$.

\section{Characterization of snake venoms}

Earlier methods for the purification, fractionation and characterization of the snake venom applied gel filtration and cation exchange without [39] or with high-performance liquid chromatography (HPLC) measurement [40]. The analysis itself was performed on reversed phase HPLC (RP-HPLC) chromatography on C-18 column, mainly with gradient (or partly isocratic) methods. A common feature of these analyses was that these venoms were initially dissolved and eluted in neutral $0.1 \mathrm{M}$ ammonium-acetate buffer or $0.1 \mathrm{M} \mathrm{NaCl}$, and the constant components of the acetonitrile and water with 0.1 $\%$ trifluoroacetic acid (TFA). The combination of the RP-HPLC and sodium dodecyl sulfate-polyacrylamide gel electrophoresis (SDS-PAGE) was already mentioned as a characterization method in the earlier publications [41], although improved RP-HPLC and SDS-PAGE profiling methods appeared later. Recently, the combination of RP-HPLC and SDS-PAGE represents a general strategy for snake venom analysis $[42,43]$. In order to characterize our $B G$ and $D A$ venoms, a Knauer HPLC equipped with C18 column $(250 \mathrm{~mm} \times 4.6 \mathrm{~mm}, 5 \mu \mathrm{m}$ particle size, YMC) was used. Eluents were HPLC grade acetonitrile (ACN) and water with $0.1 \%$ TFA. Gradient of $5 \%$ ACN for $5 \mathrm{~min}, 5-15 \%$ ACN over 20 min, $15-45 \%$ ACN over $120 \mathrm{~min}$, and $45-70 \%$ ACN over 20 min were applied with $1 \mathrm{ml} / \mathrm{min}$ flow speed. Detector wavelength was 
set to $215 \mathrm{~nm} .2 \mathrm{mg}$ lyophilized venom was dissolved in $200 \mu \mathrm{l}$ ACN-H $\mathrm{H}_{2} \mathrm{O}(5 \%), 0.1 \%$ TFA and injected to a $20 \mu \mathrm{lloop}$. Separated elution peaks were lyophilized directly from the eluent. For SDS-PAGE analysis the fractions were reconstituted in water, mixed with $2 x$ loading buffer (125 mM TrisHCl pH 6.8, 4\% SDS, $20 \%$ glycerol, $100 \mathrm{mM} \mathrm{DTT}$ ), denatured for $5 \mathrm{~min}$ at $100^{\circ} \mathrm{C}$, and were separated on 15\% SDS-polyacrylamide gel. Proteins were visualized by Coomassie-blue staining. For evaluation, we have applied a molecular weight marker/protein ladder of 10 to 180 $\mathrm{kDa}$ (Thermo Scientific, Pageruler Prestained Protein Ladder, Cat. No: 26616).

\section{Cell line}

Human thymus-derived 1889 c thymic cell line was cultured in RPMI 1640 medium (Lonza, Basel, Switzerland) supplemented with $10 \%$ fetal bovine serum (EuroClone, Pero, Italy), $2 \mathrm{mM}$ L-Glutamine (Lonza, Basel, Switzerland) and penicillin (100 $\mathrm{U} / \mathrm{mL})$ - streptomycin $(100 \mathrm{U} / \mathrm{mL})$ mixture (Lonza, Basel, Switzerland). Cells were grown at $37^{\circ} \mathrm{C}$ in a $5 \% \mathrm{CO}_{2}$ atmosphere. Cell viability was assessed prior to treatment using an EVOS XL Core Cell Imaging System (Invitrogen, Carlsbad, CA, USA).

\section{Incubation of cultured 1889 c cells with $B G$ and DA venoms}

The optimal incubation period of 1889 c cell cultures with unfractionated $B G$ and $D A$ venoms has been established by carrying out a set of experiments, to evaluate both early and late changes in gene expression. In the first experiment, $1889 \mathrm{c}$ cell cultures were treated with $0.3,1.0,3.0$ and $10 \mu \mathrm{g} / \mathrm{mL} B G$ or $D A$ venom solutions, followed by incubation at $37^{\circ} \mathrm{C}$ in a $5 \% \mathrm{CO}_{2}$ atmosphere for 2 hours. In the second experiment, thymic epithelial cells were treated with $0.1,1.0$ and $10 \mu \mathrm{g} / \mathrm{mL}$ $B G$ or $D A$ venom solutions, followed by incubation in identical conditions, but for 24 hours. The selection of the concentration range was based on previous experiences involving snake venoms and TaqMan Array technology, an experiment during which different concentrations of snake venoms solutions have been used on cell cultures, resulting in the observation that relatively high venom concentrations are required to induce a measurable effect in gene expression of ex vivo cell cultures [44]. Cells incubated without treatment served as negative control in both experiments. All treatment conditions (venom type, venom concentration, incubation time) were plated in triplicates, and cell cultures with identical treatments were pooled following incubation. The effect of different venom concentrations and incubation duration was determined by microscope evaluation and RT-qPCR (real-time quantitative polymerase chain reaction) analysis. Cell confluence was assesses by microscope image analysis using ImageJ software 1.51j8 (Additional file 1).

\section{RNA isolation and cDNA synthesis}

Total RNA was isolated from all cell cultures using a NucleoSpin RNA II kit (Macherey-Nagel, Düren, Germany) according to the manufacturer's instructions. The concentration of the isolated total RNA was determined using a Nanodrop 2000 spectrophotometer (Thermo Fisher Scientific, Waltham, MA, USA). The isolated RNA was reversed transcribed to cDNA with an Applied Biosystems 2720 Thermal Cycler system (Applied Biosystems, Foster City, CA, USA) and the High-Capacity cDNA Reverse Transcription Kit (Applied Biosystems, Foster City, CA, USA) following on the manufacturer's protocol.

\section{RT-qPCR analysis of selected apoptosis associated genes}

The effect of $B G$ and $D A$ venoms on the expression of $B A D, B A X$, CDKN1A (encoding p21), TP53 (encoding p53) and BCL2 genes (IDT, Integrated DNA Technologies, Leuven, Belgium) (for primer list see Table 1) was determined using a Quantstudio $12 \mathrm{~K}$ Flex Real-Time PCR System (Applied Biosystems, Foster City, CA, USA) with SensiFAST SYBR Hi-ROX Mix (Bioline, London, UK). Gene expression was normalized to HPRT1 housekeeping gene and the results analyzed using Expression Suite Software (version 1.1., Thermo Fisher Scientific, Waltham, MA, USA).

\begin{tabular}{lc} 
Table 1. List of primer sequences used for RT-qPCR analysis. \\
\hline Gene name & Primer sequence \\
\hline BAD-for & GAGGTCCTGAGCCGACAG \\
BAD-rev & CTTCCTCTCCCACCGTAGC \\
BAX-for & AAGAAGCTGAGCGAGT \\
BAX-rev & GCCCATGATGGTTCTG \\
BCL2-for & CATCTCATGCCAAGGGGGAA \\
BCL2-rev & ATTCTTGGACGAGGGGGTGT \\
CDKN1A-for & CTGGGGATGTCCGTCAGAAC \\
CDKN1A-rev & CATTAGCGCATCACAGTCGC \\
HPRT1-for & CTGGCGTCGTGATTAGTGAT \\
HPRT1-rev & ACATCTCGAGCAAGACGTTC \\
TP53-for & CGCTTCGAGATGTTCCGAGA \\
TP53-rev & CTTCAGGTGGCTGGAGTGAG \\
\hline
\end{tabular}

\section{TaqMan Array of apoptosis associated genes}

The expression of an extensive number of apoptosis associated genes was determined using a TaqMan Array Human Apoptosis, Fast 96-well Plate (Part No. 4418717, Applied Biosystems, Foster City, CA, USA). The TaqMan Array Plate contained 92 assays for apoptosis associated genes and 4 assays for endogenous control genes. The RT-qPCR amplification was performed on a Quantstudio 12K Real-Time PCR System (Applied Biosystems, Foster City, CA, USA) in a $10 \mu \mathrm{L}$ final volume, containing TaqMan Fast Advanced Master Mix (2x) (Applied Biosystems, 
Foster City, CA, USA) and cDNA samples from cells treated with $10 \mu \mathrm{g} / \mathrm{mL} B G$ venom, $10 \mu \mathrm{g} / \mathrm{mL} D A$ venom or untreated cells (negative control). Gene expression was analyzed using Expression Suite Software (version 1.1., Thermo Fisher Scientific, Waltham, MA, USA).

\section{Results}

\section{Snake venom analysis and selection}

The composition and activity of snake venoms show significant variation among major and minor taxonomic groups along with intra-species differences due to age, diet or geographic location. Among these, the phylogenetic variations are the most relevant [45]. Elapid venoms are characterized by the presence of small molecular weight toxins, such as three-finger toxins and $\mathrm{PLA}_{2} \mathrm{~s}$, while viperid venoms predominantly contain high molecular weight enzymes including SVMPs, LAAOs, serine-proteases and $\mathrm{PLA}_{2} \mathrm{~s}$ [45]. Consequently, we proposed to evaluate the composition and apoptosis-triggering activity of representatives of the family Elapidae (Dendroaspis angusticeps) and the family Viperidae (Bitis gabonica).

RP-HPLC analysis of the tested snake venoms showed characteristic and well-observable peaks. In case of $D A$ several peaks were identified in the timespan of 50-100 minutes of the 180 -minute analysis time (Figure 1A). In a prorated view the chromatograms presented by Petras et al. [46] show a similar pattern. Although using a different HPLC chromatographic system, major elution peaks were centered between approx. 30-60 minutes, having a total analysis time of 120 minutes. Further similarity is observed in the pattern of chromatographic records. In the middle region of peak elution four large peaks are distinguished in both analyses and several smaller ones can
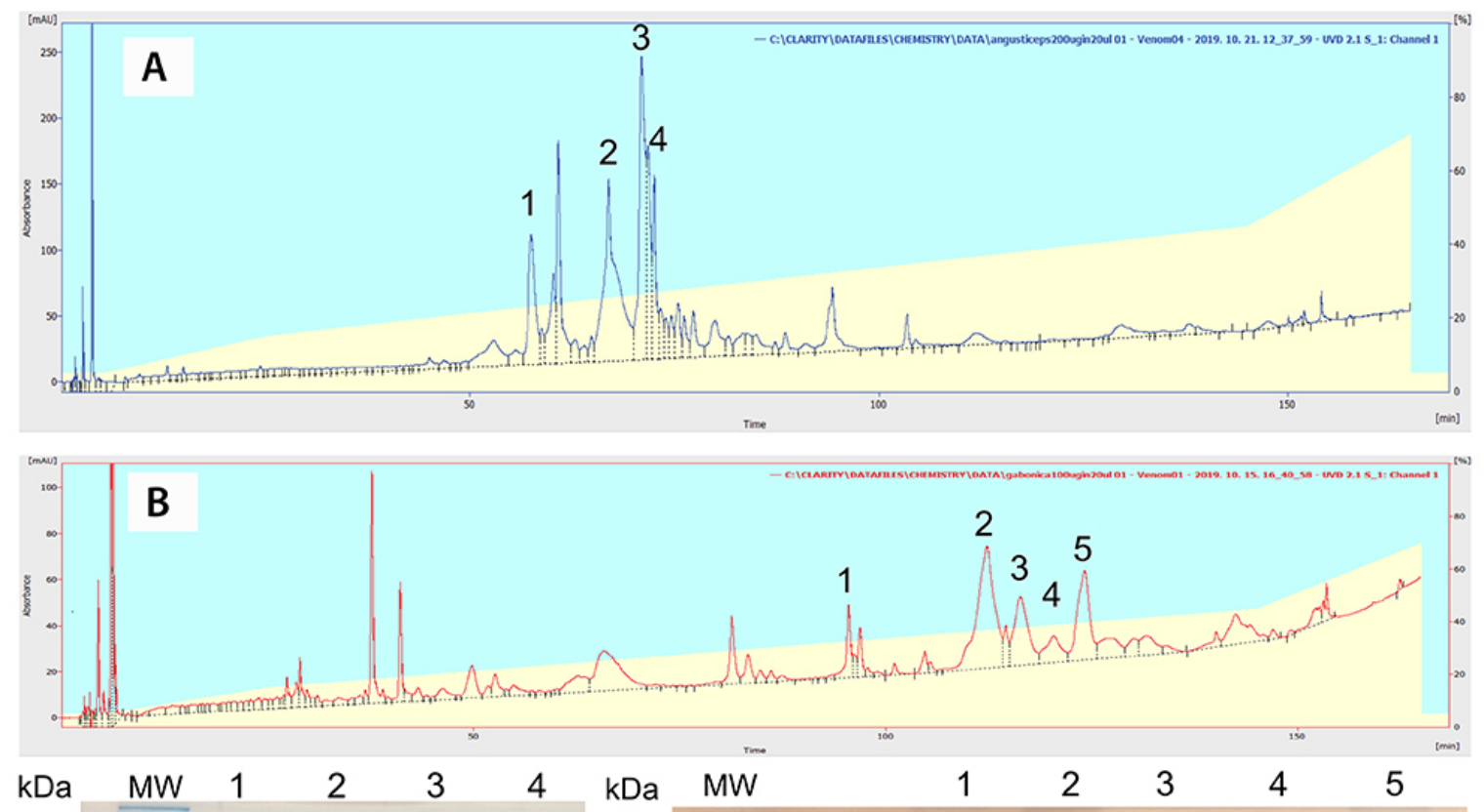

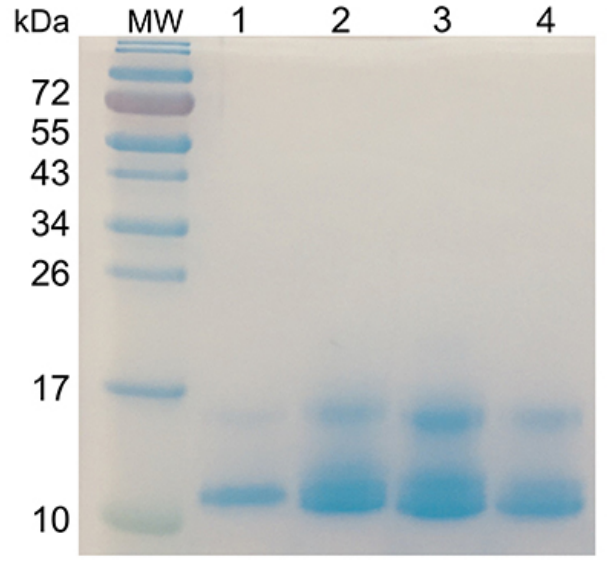

C

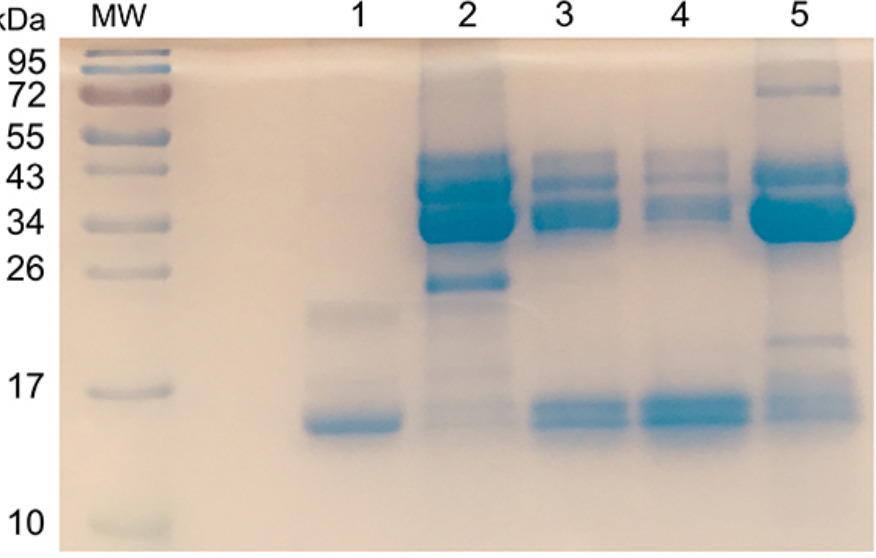

D

Figure 1. Chromatogram obtained following HPLC separation of (A) Dendroaspis angusticeps venom with four main fractions; (B) Bitis gabonica venom with five main fractions. All of these fractions have been isolated and further analysed by SDS-PAGE. Gel images show protein fractions separated based on molecular weight for (C) D. angusticeps and (D) B. gabonica. Lane numbers correspond to fraction labels isolated through HPLC separation, (A, C) 1-4 for D. angusticeps and (B, D) 1-5 for B. gabonica. The first lane on each gel contains Thermo Scientific Pageruler Prestained Protein Ladder 10 to 180 kDA (Cat. No.: 26616 ). 
also be found at higher elution times. In our study we isolated and further analyzed the most prominent proteins by SDSPAGE (Figure 1C). Our results show that low-molecular weight proteins $(10-20 \mathrm{kDa})$ are characteristic of our venom fraction. These findings are in harmony with literature data of Petras et al. [46], identifying these proteins as short- and long acting neurotoxins and dendrotoxins. Results published by Conlon et al. [47] using similar protein characterization also found lowmolecular weight F-VIII toxins in the venom of Dendroaspis angusticeps, with putative anti-tumor activity.

In contrast, HPLC run of $B G$ venom showed a wider distribution of components throughout the 180-minute elution time (Figure 1B). Similarly, the SDS-PAGE analysis revealed the presence of low molecular weight proteins from $15 \mathrm{kD}$ to the more abundant region of $30-50 \mathrm{kDa}$ (Figure 1D). The analysis of $B G$ venom showed several similarities with results published by Calvete et al. [48]. Along with a similar HPLC chromatographic pattern, SDS-PAGE analysis of the fractionated venom also revealed the presence of low-molecular weight proteins varying from 6.5 to $200 \mathrm{kDa}$. In a study conducted by Calvete et al. [49] the general characterization of Bitis species unveiled a heterogeneous composition comprising PLA ${ }_{2}$ molecules, C-type lectin-like proteins, LAAOs, serine proteases and different classes of SVMPs. In the 30-50 kDa region serine-proteases and SVMPs are typical representatives accounting for $50 \%$ of the total venom proteins, as published by Calvete et al. [49]. In addition, C-type lectins and PLA make up for 10-15\% and may also be considered as major protein components of $B G$ snake venom. The presence of these protein families predispose for PCD, and make $B G$ venom a more destructive candidate for cell demise, in comparison with $D A$ venom.

\section{Effect of incubation time and venom concentration}

Prior to performing experiments, a systematic review of available methods has been performed, to assess the possible incubation time and venom concentration needed to induce apoptosis, without leading to untimely cell death. Based on this 2-hour (short) and 24-hour (long) incubation times have been selected, with venom concentrations ranging from $0.3-10 \mu \mathrm{g} / \mathrm{mL}$ to 0.1 - $10 \mu \mathrm{g} / \mathrm{mL}$, respectively. Although the selected time points and concentrations might not overlap with lethal doses or therapeutic concentrations, these parameters were appointed for use in Petridish cultured cells in our experiments. The selected concentration also correspond to previously reported values $[44,50,51]$.

As 1889 c cell cultures were treated with $B G$ and $D A$ venoms for 2 hours and 24 hours, this allowed for the evaluation of both early and late changes in gene expression. During the 2-hour incubation $1889 \mathrm{c}$ cells have been treated with $0.3,1.0$, 3.0 and $10 \mu \mathrm{g} / \mathrm{mL} B G$ or $D A$ venom solutions, while the 24 hour incubation has been carried out with $0.1,1.0$ and $10 \mu \mathrm{g} /$ $\mathrm{mL}$ venom solutions. All treatment conditions were plated in triplicates, and cell cultures with identical treatments were pooled following incubation. The overall effect of snake venoms has been determined by microscope evaluation of the cell cultures. In comparison with untreated cells (negative control), all treatment conditions showed a decrease in the number of visible cells. Following the 2 -hour incubation period, even at the highest concentration used, only a small number of apoptoticresembling cells were visible (showing apoptotic blebs or vesicles). In contrast, the effect of snake venoms after 24-hour incubation was more pronounced, with a significant decrease of visible cells and the more frequent appearance of apoptotic-resembling cells, especially at the highest concentration of venoms used $(10 \mu \mathrm{g} /$ $\mathrm{mL}$ ). Representative microscope images showing the observed effects are shown in Additional file 2.

Further evaluation of the effect of incubation time and venom concentration was performed using conventional lowthroughput RT-qPCR analysis. The selected genes are closely related to apoptotic signaling pathways including $B A D, B A X$, $B C L 2$, CDKN1A (encoding p21) and TP53 (encoding p53). Gene expression was normalized to HPRT1 housekeeping gene, while untreated $1889 \mathrm{c}$ cells served as reference. Table 2 shows mean fold change of genes, using relative quantity (RQ) values.

The measured RQ values showed a positive correlation between incubation time and venom concentration for two genes encoding pro-apoptotic mediators ( $B A D, C D K N 1 A$ ), while the expression of $B C L 2$ gene did not show a measurable change in any condition. Based on these results and the microscope images discussed previously, samples incubated for 24 hours with $10 \mu \mathrm{g} / \mathrm{mL} B G$ or $D A$ venom have been selected for further high-throughput TaqMan Array analysis.

\section{Gene expression array in 1889 c cells treated with snake venoms}

Gene expression was assayed using the TaqMan Array Human Apoptosis Plate containing 92 apoptosis associated genes and four endogenous control genes allowing for normalization (18S, GAPDH, GUSB and HPRT1). Our data suggest a significant effect on gene expression, as almost all the studied genes showed alteration compared to baseline. The complete list of genes with the obtained RQ values is shown in Additional file 3.

For the purpose of this work, we have selected genes that presented changes over $\log 2 \mathrm{RQ} \geq \pm 1.0$ values $(+10 \%$ tolerance limit giving $>1.8 \mathrm{RQ}$ or $<0.55 \mathrm{RQ}$ ). Based on these criteria, 16 genes have been identified in the $B G$ treatment group and 10 genes in the $D A$ treatment group.

\section{Gene expression in 1889 c cells treated with BG venoms}

1889 c cells treated with $B G$ venom expressed a significant variation in the fold change of 16 genes associated with apoptosis (Figure 2). The most significant change (approx. 2.5 million-fold increase) was observed in the case of CASP5, the gene encoding inflammatory protease caspase-5. Since the fold change measured for this gene was unusually high, a dedicated conventional RT-qPCR measurement has also been performed for CASP5 expression and confirmed this value. Other up-regulated genes 
Table 2. Relative quantity (RQ) values of gene expression measured 2-hour and 24-hour after treatment of $1889 \mathrm{c}$ cells with BG or DA venom. Treatment conditions were plated in triplicates then pooled following incubation. Untreated cells served as reference (baseline).

\begin{tabular}{|c|c|c|c|c|c|c|}
\hline \multirow{2}{*}{$\begin{array}{l}\text { Sample } \\
\text { Venom }\end{array}$} & \multicolumn{6}{|c|}{ RQ values of target genes } \\
\hline & $\begin{array}{c}\text { Incubation } \\
\text { time (h) }\end{array}$ & Conc. $(\mu \mathrm{g} / \mathrm{mL})$ & $B A D$ & $B A X$ & CDKN1A & TP53 \\
\hline \multirow{7}{*}{ BG } & \multirow{4}{*}{2} & 0.3 & 0.916 & 0.999 & 1.077 & 1.116 \\
\hline & & 1.0 & 0.872 & 0.989 & 1.109 & 1.076 \\
\hline & & 3.0 & 0.868 & 0.999 & 1.133 & 1.087 \\
\hline & & 10 & 0.937 & 1.093 & 1.414 & 1.166 \\
\hline & \multirow{3}{*}{24} & 0.1 & 0.142 & 0.074 & 0.436 & 1.222 \\
\hline & & 1.0 & 0.515 & 0.664 & 1.043 & 0.946 \\
\hline & & 10 & 0.405 & 0.703 & 1.866 & 0.822 \\
\hline \multirow{7}{*}{$D A$} & \multirow{4}{*}{2} & 0.3 & 0.867 & 0.850 & 1.193 & 0.817 \\
\hline & & 1.0 & 0.805 & 0.887 & 1.545 & 0.801 \\
\hline & & 3.0 & 0.767 & 0.837 & 1.823 & 0.760 \\
\hline & & 10 & 0.765 & 0.867 & 2.120 & 0.707 \\
\hline & \multirow{3}{*}{24} & 0.1 & 0.806 & 0.941 & 1.108 & 0.893 \\
\hline & & 1.0 & 0.784 & 0.867 & 1.056 & 0.777 \\
\hline & & 10 & 1.402 & 1.019 & 1.677 & 0.767 \\
\hline
\end{tabular}

of the caspase gene group included CASP4 (2.47-fold increase), encoding inflammatory protease caspase-4, CASP10 (2.30-fold increase), encoding apoptosis initiator caspase-10 and CASP14 (9.40-fold increase), encoding caspase-14, also known to be involved in keratinocyte differentiation. On the other hand, the treatment resulted in the down-regulation of CASP9, the gene encoding caspase-9 $(\mathrm{RQ}=0.15)$.

Members of NOD and leucine-rich repeat containing proteins gene group showed a significant increase in expression level. The NLRP1 gene, encoding NLRP1, showed a 15.52-fold increase, while NAIP, the gene encoding NLR family apoptosis inhibitory protein (NAIP) presented a 2.49 -fold increase.

A significant effect of $B G$ venom was observed on genes of the apoptosis regulator $\mathrm{Bcl} 2$ family. The assessed up-regulated genes encoding anti-apoptotic Bcl2 family members included BCL2 (2.56-fold increase), BCL2A1 (2.88-fold increase), BCL2L10 (5.08fold increase), and MCL1 (2.17-fold increase). Simultaneously, the gene BNIP3L, encoding the pro-apoptotic mediator Bcl2/ adenovirus E1B $19 \mathrm{kDa}$ protein-interacting protein 3-like (BNIP3L) displayed a 2.07-fold increase, while $H R K$, encoding the activator of apoptosis harakiri (HRK) protein presented a 0.4 -fold decrease in gene expression.

Other noteworthy findings include the up-regulation of BIRC3 (3.40-fold increase), the gene encoding baculoviral IAP repeat containing protein 3 (BIRC3) and TNFSF10 (1.90-fold increase), encoding TRAIL. Furthermore, $C A R D 9$, the gene encoding the CARD9 protein, displayed a 0.016 -fold decrease in its expression.

\section{Gene expression in 1889 c cells treated with $D A$ venom}

The treatment of 1889 c cells with $D A$ venom led to the significant variation in the expression of ten genes associated with apoptosis (Figure 3). Among these genes, the most relevant up-regulation has been observed in the case of BIRC7 (6.46-fold increase), the gene encoding apoptotic mediator BIRC7. Two members of the $\mathrm{Bcl} 2$ family have been up-regulated, namely BCL2L10 (2.3-fold increase) and $H R K$ (1.86-fold increase). Further up-regulated genes included $C A R D 9$ with a 4.13 -fold increase, $F A D D$ with a 2.39 -fold increase and NFKBIA with a 1.98 -fold increase. The $F A D D$ gene encodes the pro-apoptotic mediator FADD, while NFKBIA encodes nuclear factor kappa-light-chain-enhancer of activated $B$ cells (NF- $\kappa B$ ) inhibitor alpha (I $\kappa \mathrm{B} \alpha$ ).

Down-regulated genes included CARD6 (0.49-fold decrease), CASP1 (0.30-fold decrease), LTB (0.44-fold decrease) and NOD2 (0.40-fold decrease). These genes encode CARD6, caspase-1, lymphotoxin beta and NOD2, respectively.

\section{Discussion}

\section{Overview of programmed cell death mechanisms}

Apoptosis, or type I PCD, plays an essential role in the selective removal of cells that are either damaged or no longer required during development or growth $[52,53]$. Apoptosis is characterized by distinct morphological changes, such as cell contraction, nuclear fragmentation, membrane bleb formation and loss of adherence [1]. The defective function of apoptotic 


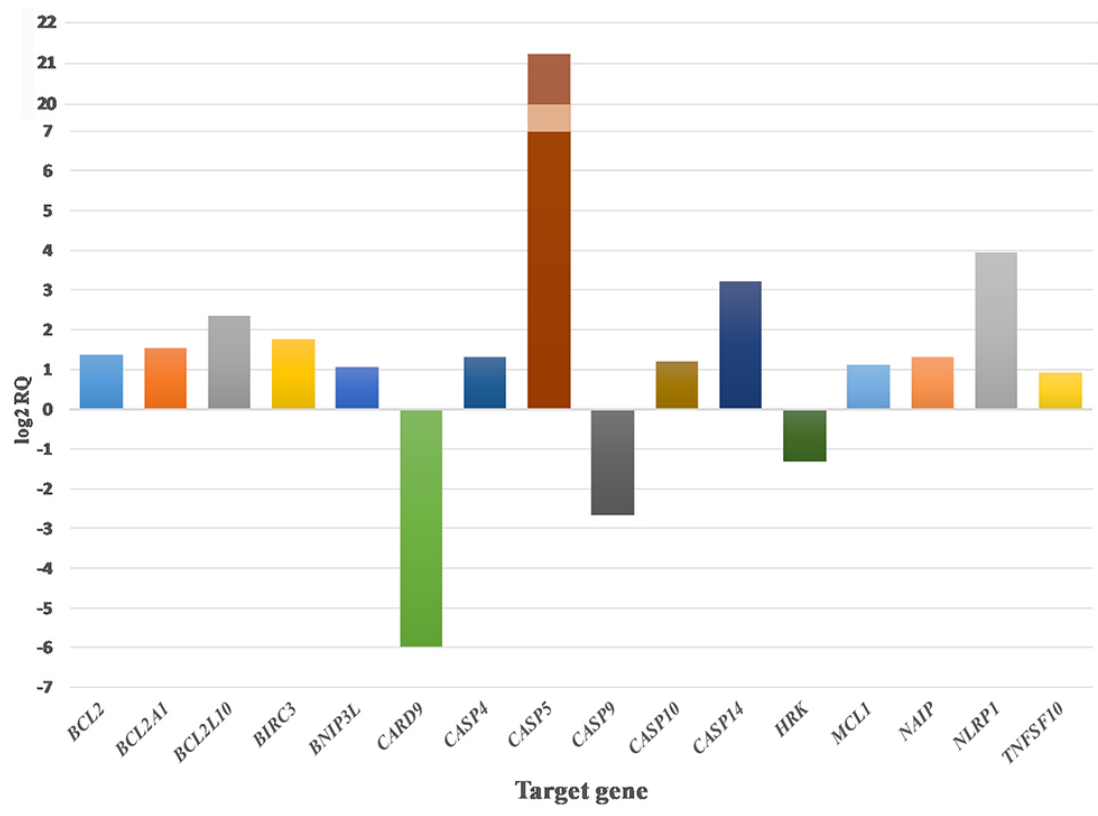

Figure 2. Up- and downregulated genes in 1889c cells treated with $10 \mu \mathrm{g} / \mathrm{mL}$ of $B G$ venom. Values are shown using a log2 RQ-based scale. Untreated cells served as baseline (represented by value 0 of $Y$ axis). The +1 and -1 values represent a two-fold increase or decrease threshold.



Target gene

Figure 3. Up- and downregulated genes in $1889 \mathrm{c}$ cells treated with $10 \mu \mathrm{g} / \mathrm{mL} D A$ venom. Values are shown using a log2 RQ-based scale. Untreated cells served as baseline (represented by zero value of $Y$ axis). The +1 and -1 values represent the two-fold increase or decrease threshold.

mechanisms can lead to an accumulation of undesired cells in the tissues, resulting in cancer development [54], as well as autoimmune [55] or inflammatory diseases [56]. On the other hand, excessive apoptosis can cause tissue damage [53] or even severe neurodegenerative diseases [57].

There are two distinct pathways by which apoptosis can be triggered $[53,58]$. The intrinsic (mitochondrial) pathway involves mitochondrial outer membrane permeabilization (MOMP), regulated by pro- and anti-apoptotic Bcl-2 family members [2].
MOMP leads to the release of mitochondrial proteins, including cytochrome C. This binds to the apoptotic protease activating factor 1 (APAF1), leading to the formation of the apoptosome complex [59]. The apoptosome cleaves pro-caspase-9, generating active caspase-9, a major initiator of mitochondrial apoptosis, that in turn activates caspase-3 $[1,60]$.

The extrinsic (death receptor) pathway of apoptosis is primarily triggered through membrane-bound death receptors (DR) that belong to the tumor necrosis factor (TNF) superfamily [53]. 
These include TNF receptor 1 (TNFR1), Fas receptor (FasR), death receptor 3 (DR3), TNF-related apoptosis-inducing ligand (TRAIL) receptor 1 (TRAILR1, DR4), TRAIL receptor 2 (TRAILR2, DR5) and death receptor 6 (DR6) [1,61]. The binding of mediators containing a death domain (DD) to these receptors initiates the signal for apoptosis. Examples include TNF- $\alpha$ and TNFR1, Fas ligand (FasL) and FasR, TNF-like protein 1 (TL1A) and DR3, and between TRAIL and TRAILR1/2 [1,53,62]. Ligandreceptor binding induces the recruitment of adaptor proteins with a death-effector domain (DED), such as Fas-associated death domain (FADD) or TNFR-associated death domain (TRADD) $[53,63]$. These in turn recruit pro-caspase- 8 and pro-caspase-10, forming the death-inducing signaling complex (DISC) and activate the ligated caspases. Caspase- 8 and caspase- 10 function as initiator caspases and are responsible for the cleavage and activation of effector caspases, e.g. caspase-3, caspase-7 [62,64].

Autophagy, or type II PCD, is the process of self-degradation of cellular components associated with nutrient deprivation, pathogen infection and other intra- or extracellular stress sources [65]. Through autophagy, cellular components, protein aggregates, damaged organelles and invasive pathogens are degraded by the formation of autophagosomes. [2]. While the main function of autophagy is the promotion of cell survival under extreme conditions, an over-activation of autophagic mechanisms may result in cell death $[66,67]$.

As the primary role of autophagy is the promotion of cell survival, it is capable of suppressing apoptosis. However, in some cases, autophagy leads to cell death, either in association with apoptosis, or as a secondary mechanism if the apoptotic pathways are inhibited. As such, there is a relevant and extensive crosstalk between pathways related to autophagy and apoptosis [2,67].

Regulated necrosis, or type III PCD, involves the swelling of organelles and cells, cell lysis and release of intracellular contents $[1,68,69]$. The most studied form of regulated necrosis is named necroptosis, which uses a unique signaling pathway, namely receptor-interacting protein kinase-1 and -3 (RIPK1, RIPK3), that may be specifically inhibited by necrostatins [68]. Known activators of necroptosis include TNF- $\alpha$, FasL, TRAIL (initiators of the extrinsic apoptotic pathway), genotoxic stress, anticancer drugs, lipopolysaccharides, interferons, etc. [68,69].

Relatively well-known types of regulated necrosis include the mitochondrial permeability transition dependent regulated necrosis $[69,70]$ and parthanatos, which relies on the activation of poly(ADP-ribose) polymerase 1 and the release of apoptosisinducing factors [70-72]. Other forms of regulated necrosis include ferroptosis, an iron-dependent form of non-apoptotic cell death [73], pyroptosis, a caspase-1-dependent inflammatory cell death [74], and pyronecrosis, which requires cathepsin B and apoptosis-associated speck-like protein containing caspase recruitment domain [69,75].

Pyroptosis is a purposeful form of PCD, as regulated necrosis, in which inflammatory caspases, mainly caspase-1 (canonical pathway), -4 , and -5 (non-canonical pathway) occupy a cardinal role, leading to the maturation of pro-inflammatory cytokines inside an inflammasome [76,77]. Initiator sensors like nucleotidebinding oligomerization domain (NOD), leucine rich repeat and pyrin domain containing-1 and -3 (NLRP1, NLRP3), and NLR (NOD-like receptor) family CARD (caspase activation and recruitment domain)-containing protein 4 (NLRC4) also play a role [78]. Novel insights concerning the underlying mechanisms of pyroptosis reveal an important role of gasdermin $\mathrm{D}$, the primary effector molecule in pyroptosis $[79,80]$. To date, pyroptosis, as an important regulator of homeostatic equilibrium in vivo, has been described in antimicrobial host defense mechanisms [81], various pathologies, e.g. cancer [82] and as a defense mechanism against noxious xenobiotics, e.g. venoms [28].

\section{Effect of BG venom on gene expression}

Members of the NLR family, e.g. NLRP1, NLRP3, are implicated in the recruitment of inflammatory caspases to the inflammasome [83]. Recent evidence published by Youm et al. [84] provided new insights of NLRP induced inflammasome formation and its role in the thymus. Immune-senescence and thymic cell death may be delayed by blocking the pathway resulting in inflammasome production, as observed in NLRP3 ${ }^{-/-}$mice. Our findings suggest that pyroptosis driven inflammasome production, and not classical apoptosis, might be the main cause of cell demise. Significant up-regulation of NLRP1 gene (15.52-fold) along with genes encoding inflammatory caspases CASP4 (2.47-fold) and CASP5 (2,450,677-fold increase) in thymic carcinoma cells corroborate with the findings of Youm et al. [84] and suggest an alternative $P C D$ pathway triggered by $B G$ venom in thymic cells (Figure 4).

Caspase-mediated apoptosis induced by different snake venom fractions, for example LAAOs, has been observed by Alves et al. [85]. The apoptotic potential of Bothrops atrox LAAOs has been correlated with increased levels of caspase- 3 and caspase-9 in HL60, Jurkat, PC12 and B16F10 cell lines [85]. In a communication disclosed by Santos et al. [86] caspase-3 mediated apoptosis of rabbit skeletal muscle myocytes has been attributed to envenomation with Bothrops alternatus. Tavares et al. [87] have shown that Calloselasma rhodostoma SV-LAAOs might contribute to cytotoxic cellular events by the activation of caspase- 3 and caspase- 8 in hyperproliferative myeloid cells. In another study, published by Costal-Oliveira et al. [88] an LAAO from Bothrops atrox has been shown to contribute to autophagy-induced apoptosis by increasing the oxidative stress in the immediate microenvironment or by triggering various intracellular substrates of keratinocytes. Snake venom LAAOs show diversified metabolic activities that elicit various proapoptotic pathways, mainly through the elevation of caspase activity and through oxidative stress.

Increased caspase activity produced by envenomation with the snake venoms from the Viperidae family seems to be characteristic. In a study presented by Shahbazi et al. [4] the cytotoxic effect of Pseudocerastes persicus has been observed in normal fibroblast cells (Hu02) and lung cancer cells (A549) through the activation of caspase- 3 and caspase-9. HPLC 


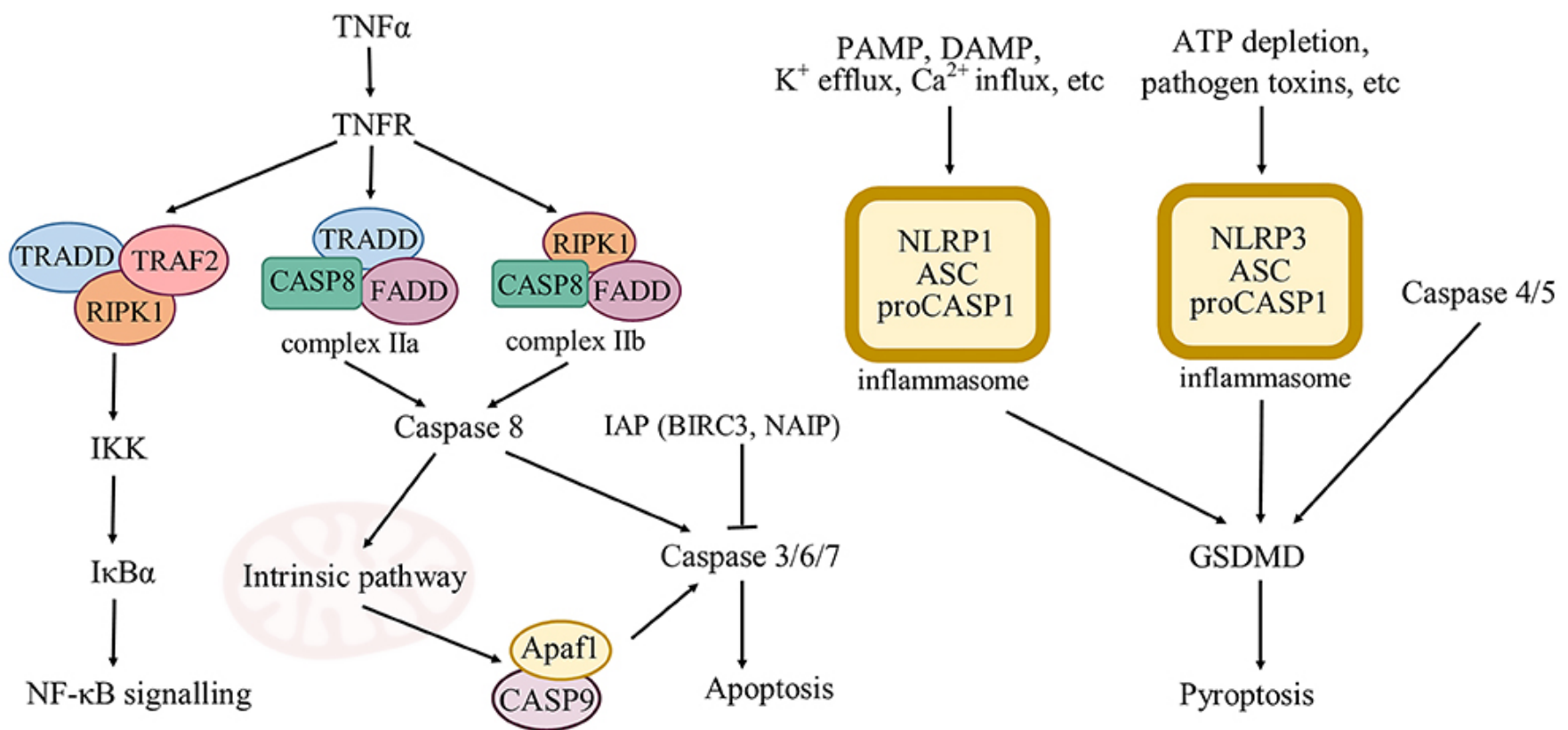

Figure 4. Representative apoptosis-related genes and pathways activated by BG venom in 1889c cells. TNF: tumor necrosis factor; TNFR: tumor necrosis factor receptor; TRADD: TNFR associated death domain; TRAF: TNFR associated factor; RIPK: receptor-interacting protein kinase; IKK: inhibitor of nuclear factor kappa-B kinase; NF-KB: nuclear factor kappa-light-chain-enhancer of activated B cells; FADD: Fas-associated death domain; APAF: apoptotic protease activating factor; IAP: inhibitor of apoptosis protein; NLRP: NLR family pyrin domain containing protein 1; GSDMD: gasdermin D; BIRC: baculoviral IAP repeat containing protein; NAIP: NLR family apoptosis inhibitory protein; ASC: caspase recruitment domain; PAMP: pathogen-associated molecular pattern; DAMP: damageassociated molecular pattern.

fractioning of crude snake venom revealed that fraction 21 activated the intracellular apoptotic pathways, putatively belonging to the class of SVMPs. In this view, SVMP fractions present in the BG venom might explain the well-marked elevation of caspases in thymic epithelial cells.

Activation of cell apoptosis through the main effector caspase molecules is characteristic to venoms of animal origin. In a recent article published by Ceremuga et al. [89] the apoptotic activity of melittin, a bee venom fraction, has been correlated with elevated caspase- 3 and caspase- 7 levels in a dose- and time-dependent manner. Boeno et al. [90] have shown that purified Lys49-PLA2 homologue from Bothrops jararacussu might contribute to inflammasome formation through the activation of NLRP3, which in turn interacts with caspase-1, leading to an inflammatory response via IL-1 $\beta$. PLA2 mediated inflammatory response was observed by Cedro et al. [91]. Using purified Asp49-PLA2 (5, 10 and $20 \mu \mathrm{g} / \mathrm{mL})$ from Bothrops jararaca snake venom, an increased level of IL-6, IL- $1 \beta$ and PGE2 was described through neutrophil stimulation, although its cytotoxic activity is inferior to those observed in case of the Lys49-PLA2 homologue structure. NLRP3 inflammasome formation and subsequent secretion of inflammatory cytokines was also described by Zoccal et al. [92] in mice envenomed with Tityus serrulatus scorpion venom.

Representatives of the TNF superfamily are enrolled in the activation of both pro- and anti-apoptotic cell mechanisms. On one hand, TNFs induced extrinsic apoptosis via TRADD/
FADD activated caspase-8/caspase-10, through caspase-3,-6,-7. Apoptosis regulator $\mathrm{BAX}(\mathrm{BAX}) / \mathrm{Bcl} 2$-associated agonist of cell death (BAD)/phorbol-12-myristate-13-acetate-induced protein 1 (NOXA) represents an important regulatory pathway in cells, leading to ripoptosome (complex IIa or complex IIb) formation as a result of FADD/caspase-8 interaction. On the other hand, TNFs are prone to activate anti-apoptotic mechanisms, promoting RIPK-1 ubiquitination, thus marking it for proteosomal degradation, and subsequently inhibiting the RIPK-1-mediated recruitment of FADD and caspase-8 [93]. Our measurements showed an indicative trend towards down-regulation of the genes encoding effector molecules participating in the pro-apoptotic events inside thymic epithelial cells, namely $F A D D(0.68$-fold decrease) and TRADD (0.62-fold decrease), and no significant increase in the level of CASP8. This observation is in accordance with current consensus on cell death [94], stating that in "type I cells" caspase- 8 mediated apoptosis cannot be inhibited by over-expression of Bcl-2 family members. This indicates that not apoptosis, but rather PCD may lead to the massive death of thymic epithelial cells. Moreover, recent studies confirmed negative regulation of caspase-10 on caspase-8, thereby inhibiting cell death. Furthermore, the study presented by Horn et al. [95] associates a role in cell survival to caspase-10 by favoring NF- $\kappa B$ signaling via RIPK-1 activation and subsequent IкBa phosphorylation. Our results are in harmony with these observations, as an increase in both CASP10 (2.30-fold increase) and RIPK1 (1.53-fold increase) genes is observed, which may 
explain the elevated levels of survival genes activated through NF- $\kappa \mathrm{B}$ signaling.

Mutual interaction between members of the TNF superfamily and Bcl-2 family is also of key importance in the regulation of cell fate. Under apoptotic stimuli, anti-apoptotic events are prone to exacerbate in order to overcome the noxiousness of these extracellular impacts. Protective effects of BCL-2 under TRAIL-induced apoptosis was demonstrated by Sun et al. [96]. Snake venoms have been reported to contribute to the activation of the cytokine network and induce intracellular inflammatory processes [44]. Similarly, in the present study, a tendency towards over-expression of TNFs was observed. In addition, as a response to inflammatory stimuli, members of the Bcl-family (BCL2A1 and BCL2L10) showed a considerable increase in gene expression (2.88- and 5.08-fold, respectively). Furthermore, although TNFmediated caspase activation is realized via TRADD/FADD, TNF activated and NF- $\kappa \mathrm{B}$-mediated anti-apoptotic gene transcription (Bcl-family members, inhibitors of apoptosis proteins (IAPs)) is alternatively induced via RIPK1 and TNF receptor-associated factor 2 (TRAF2) [97]. In this context, our recent findings indicate that due to a somewhat down-regulated FADD and TRADD, TNF activity shifted towards NF- $\kappa$ B induced antiapoptotic signaling, putatively as a response mechanism to an existing inflammation due to envenomation. This tendency might also be augmented by the somewhat increased expression of CHUK (1.63-fold increase), the gene encoding the inhibitor of nuclear factor kappa-B kinase subunit alpha (IKK- $\alpha$ ), thus contributing to the NF- $\kappa \mathrm{B}$ mediated signal transduction.

Increased caspase activity is generally related to apoptotic processes [98]. IAPs are molecular structures, which inhibit caspase activity and caspase-mediated apoptosis. Katagiri et al. [99] disclosed a dual regulatory effect of NAIP in macrophages as a response to Legionella infection by inhibiting apoptotic events through APAF-1 down-regulation and simultaneous triggering of inflammasome activation. The observation made by Katagiri et al. [99] and the over-expression of NAIP gene (2.49-fold increase) under the effect of $B G$ venom suggests that NAIP is potentially contributing to the anti-apoptotic regulatory mechanisms inside cells, representing a viable explanation for the metabolic shift favoring pyroptosis under the tested conditions. Moreover, BIRC3 gene, encoding a key IAP in the regulation of cell death showed a 3.40-fold increase. This observation further emphasizes cellular communication towards NF- $\kappa \mathrm{B}$, as BIRC3 activation is NF- $\kappa \mathrm{B}$ dependent [100].

Caspase-14 activity was identified in epithelial differentiation, being activated independent of apoptotic or inflammatory stimuli [101]. Its main biological function lies in the differentiation of keratinocytes of the epidermis, but caspase-14 activity was also described in the Hassall's bodies of the thymus [102]. Novel findings describe caspase-14 as a phylogenetically closely related protein to pyroptosis initiator caspases [103]. Recent advances in the elucidation of the anatomic characterization and metabolic role of Hassall's bodies reveal a heterocellular anatomic structure, consisting of thymic epithelial cells, macrophages, dendritic-, myoid-, mast cells and lymphocytes suggesting a role in lymphopoiesis [104]. In this view, increased gene expression of CASP14 (9.40-fold) might be the result of a characteristic metabolism of thymic epithelial cells, similar to that previously reported in other epithelial cells.

\section{Effect of DA venom on gene expression}

In contrast to the observations made regarding the effect of $B G$ venom, in the case of $D A$ venom the increase of apoptosis related genes is more profound, while other inflammatory, or pyroptosis initiator members are generally silenced (Figure 5). In contrast to $B G$ venom, under the noxious effect of $D A$ venom there is a notable down-regulation of CASP1 $(\mathrm{RQ}=0.30)$. The lack of inflammatory response, leading to inflammasome formation, is also sustained by the down-regulated TNF (RQ $=0.59$ ). The correlation between TNF- $\alpha$ and caspase- 1 is of key importance during necroptosis, as several studies described a direct activation of caspase-1 by TNF- $\alpha$ [105-107].

From another perspective, the 1.5-fold increase of TNFRSF21 (encoding DR6), represents a tendency towards TNF-induced apoptosis in thymic epithelial cells. DR6 was identified as a receptor regulating various cellular events through c-Jun $\mathrm{N}$-terminal kinase (JNK) and NF- $\kappa \mathrm{B}$ signaling, being expressed in most cell types, including the thymus $[108,109]$. Recently, Etemadi et al. [110] reported that lymphotoxin $\alpha$ (LT- $\alpha)$ can induce apoptosis and necroptosis in a similar manner as TNF- $\alpha$ by different intracellular cell-fate mechanisms. The marginal elevation of both TNFRSF21 and LTA (1.69-fold) genes may shed novel insight on TNF receptor-induced cell survival. To date, no representative activators of DR6 have been identified. Based on our results, we propose that LT- $\alpha$, through DR6, contributes to two distinct cell-fate mechanisms.

On one hand, this ligand-receptor complex can induce apoptosis by activating FADD and TRADD. This is in part confirmed by our study, as FADD and the gene encoding its adaptor protein $L R D D$ are elevated to some extent (2.39-fold and 1.55-fold, respectively), but TRADD presented negligible change in gene expression (1.16-fold). Also, despite the fact that FADD is significantly over-expressed, no other important changes were observed in the levels of initiator and effector caspases downstream in this cascade. On the other hand, TNF-receptors contribute to apoptosis via JNK signaling, as downstream of JNK activation pro-apoptotic genes are primarily expressed, e.g. HRK, which presents a significant, 1.86-fold increase in our case. Finally, TNF-receptors are able to activate IKKs, resulting in NF- $\kappa \mathrm{B}$ activation and gene transcription of various survival genes. Under the effect of $D A$ venom, anti-apoptotic survival genes BCL2L10 and BIRC7 showed a noticeable up-regulation of 2.30-fold and 6.47-fold, respectively. Other studies described the activation of both canonical and non-canonical NF- $\kappa \mathrm{B}$ pathways by LTs via classical lymphotoxin beta receptor activation $[111,112]$, which might support this dual effect of LT-driven cell fate mechanisms. FADD-independent, MAPK-activated and ERK inactivated apoptotic stimuli have been described by Liu 




Figure 5. Representative apoptosis-related genes and pathways activated by DA venom in human thymic epithelial cells. LTA: lymphotoxin a; TNFR: tumor necrosis factor receptor; TRADD: TNFR associated death domain; FADD: Fas-associated death domain; RIPK: receptor-interacting protein kinase; LRDD: leucine-rich repeats and death domain; MAPK: mitogen activated protein kinase; TRAF: TNFR associated factor; HRK: harakiri; IKK: inhibitor of nuclear factor kappa-B kinase; NF-kB: nuclear factor kappa-light-chain-enhancer of activated B cells; JNK: c-Jun N-terminal kinase; NOD: nucleotide-binding oligomerization domain; CMB: CARD-BCL-MALT complex; Bcl: B-cell lymphoma; BIRC: baculoviral IAP repeat containing protein.

et al. [113] on human leukemia U937 cells following treatment with protease inhibitor-like protein-1 (PILP-1) obtained from Bungarus multicinctus snake venom.

As NF- $\kappa$ B is a self-regulatory communication system, under powerful activator stimuli, it also induces the inhibitors of NF$\kappa \mathrm{B}$, including $\mathrm{I} \kappa \mathrm{B} \alpha(N F K B I A)$ [114]. This would explain the 1.98-fold increase in the NFKBIA gene expression in our study.

TRAIL-linked apoptosis, through an over-expression of DR receptors, namely DR4 and DR5 via JNK signaling was described by Park et al. [115] in the presence of Vipera lebetina turanica snake venom. Moreover, the tested venom proved to elevate major apoptotic caspases, while the anti-apoptotic proteins, contrary to our results, were depleted. Such differences may be explained by the difference in snake venom composition, as elapid venoms are primarily neurotoxic, while viper venoms are more likely to trigger programmed cell death. Viper snake venoms are generally comprised of SVMPs, SVSPs and PLA, whilst elapid venoms are dominated by PLA ${ }_{2}$ and 3FTxs [116]. Conlon et al. [47] have described the cytotoxic activity of two peptides belonging to the 3FTx superfamily isolated from $D$. angusticeps venom, C13S1C1 which proved to be cytotoxic against breast and colorectal adenocarcinoma cells, and toxin
F-VIII which proved to be less potent than the C13S1C1 fraction. Furthermore, several studies elucidate the anticancer activity of snake venoms in various carcinoma cell lines. Elapidae venoms are prone to activate effector caspases, such as CASP3 in carcinoma cell lines, and are also prone to induce oxidative stress, or to disrupt the oxidative phosphorylation, and thus cut off the energy household [15,117-119].

CARDs are known as protein interaction modules, implicated in protein interactions required for apoptosis and immunity [120]. The CARD9 signalosome is known to mediate NF- $\kappa$ B and mitogen-activated protein kinase (MAPK) signaling, although the exact mechanisms underlying this activation process and the outcome of these molecular interactions are yet to be elucidated [121]. Similarly, recent studies describe the majority of CARDs as NF- $\kappa \mathrm{B}$ activators, via the formation of several signaling complexes, like nodosomes (NOD1 and NOD2) and CMB (CARD-BCL-MALT complex), having a regulatory effect over the aforementioned pathways [122]. In our study expression of NF- $\mathrm{BB}$-activator CARDs was inconclusive, as CARD9 showed a 4.13-fold increase, while CARD6 and CARD15 were notably suppressed showing 0.49 - and 0.40 -fold expression, respectively. 


\section{Conclusion}

Our work draws attention to the possible effect of snake envenomation at the level of sub-cellular pathways within the thymic epithelium. Biological toxins (e.g. snake venoms tested here from B. gabonica and D. angusticeps) can potentially trigger immune senescence of the central immune system (thymus) through apoptotic pathways (e.g. pyroptosis). The subsequent sudden loss in fresh naive T-cell production may lead to elevated chances of secondary immune pathologies such as infection, cancer and auto-immunity, later in life. This not only hampers quality of life, but also poses significant burden on the healthcare and social system, supporting our research.

\section{Abbreviations}

CAN: acetonitrile; APAF: apoptotic protease activating factor; BAD: Bcl2-associated agonist of cell death; BG: Bitis gabonica; BIRC: baculoviral IAP repeat containing protein; CARD: caspase activation and recruitment domain; DA: Dendroaspis angusticeps; DD: death domain; DED: death-effector domain; DISC: death-inducing signaling complex; DR: death receptor; FADD: Fas-associated death domain; FasL: Fas ligand; FasR: Fas receptor; HPLC: high performance liquid chromatography; HRK: activator of apoptosis harakiri; IAP: inhibitors of apoptosis proteins; IKK: inhibitor of nuclear factor kappa-B kinase; IкBa: NF- $\kappa B$ inhibitor alpha; JNK: c-Jun N-terminal kinase; LAAO: L-amino acid oxidase; LT: lymphotoxin; MAPK: mitogenactivated protein kinase; MOMP: mitochondrial outer membrane permeabilization; NAIP: NLP family apoptosis inhibitory protein; NF- $\kappa B$ : nuclear factor kappa-light-chain-enhancer of activated B cells; NLR: nucleotide-binding oligomerization domain (NOD)-like receptor; NLRP: nucleotide-binding oligomerization domain, leucine rich repeat and pyrin domain containing; NOD: nucleotide-binding oligomerization domain; NOXA: phorbol-12-myristate-13-acetate-induced protein 1; PBS: phosphate buffered saline; PCD: programmed cell death; PLA2: phospholipase A2; RIPK: receptor-interacting protein kinase; RP-HPLC: reversed phase high-performance liquid chromatography; RQ: relative quantity; RT-qPCR: real-time quantitative polymerase chain reaction; SDS-PAGE: sodium dodecyl sulphate-polyacrylamide gel electrophoresis; SVMP: snake venom metalloproteinase; TFA: trifluoroacetic acid; TL1A: TNF-like protein 1; TNF: tumor necrosis factor; TNFR: TNF receptor; TRADD: TNF receptor-associated death domain; TRAF: TNF receptor-associated factor; TRAIL: TNF-related apoptosis-inducing ligand.

\section{Acknowledgments}

The authors would like to thank Orsolya Péterfi for her support provided in the writing of this manuscript.

\section{Availability of data and materials}

All data generated or analysed during this study are included in this article.

\section{Funding}

FB was the recipient of a joint scholarship from the StudiumProspero Foundation, State Secretariat for National Policy of Hungary and Bethlen Gabor Fund. Scientific research support was provided by PTE SZKK-K, AOK KA-2019, PTE PoP (FIKP II), Janos Bolyai Scholarship of the Hungarian Academy of Sciences and Bolyai+ 2018/2019 (UNKP-18-4 2019/2020 aka new national excellence program of the ministry of human capacities) to KK. This work was also supported by the EFOP-3.6.1-16-2016-00004, GINOP-2.3.2.-15-2016-00022 and TUDFO/51757-1/2019-ITM to KK, the UNKP-18-3-I 2019/2020 aka new national excellence program of the ministry of human capacities and the UNKP19-3-I and ÚNKP-19-3-IV 2019/2020 new national excellence program of the ministry for innovation and technology to KG and KB and CEEPUS CIII-RO-0010-13-1819-M-124960 mobility to FB.

\section{Competing interests}

The authors declare that they have no competing interests.

\section{Authors' contributions}

$\mathrm{KK}, \mathrm{KB}$ and $\mathrm{KG}$ conceived this research and designed experiments. FB, KB, KG, DS, RLS, RC and TC performed experiments and analysis. $\mathrm{FB}, \mathrm{BK}$ and $\mathrm{AA}$ participated in the design and interpretation of the data. $\mathrm{FB}, \mathrm{BK}$ and $\mathrm{KK}$ wrote the paper and participated in the revisions of it. All authors read and approved the final manuscript.

\section{Ethics approval}

Not applicable.

\section{Consent for publication}

Not applicable.

\section{Supplementary material}

The following online material is available for this article:

Additional file 1. Cell confluence assessment by microscope image analysis (ImageJ software 1.51j8) for representative images presented in Additional file 2.

Additional file 2. Representative microscope images of 1889c cell cultures following (A-C) 2-hour or (D-F) 24-hour incubation with snake venoms. (A, D) Untreated cells (negative control); (B, E) $10 \mu \mathrm{g} / \mathrm{mL}$ Bitis gabonica venom; (C, F) $10 \mu \mathrm{g} / \mathrm{mL}$ Dendroaspis angusticeps venom.

Additional file 3. Relative quantification (RQ) values measured following the 24-hour treatment of $1889 \mathrm{c}$ with either $10 \mu \mathrm{g} / \mathrm{mL}$ Bitis gabonica venom or $10 \mu \mathrm{g} / \mathrm{mL}$ Dendroaspis angusticeps venom. Untreated cells served as reference (negative control). 


\section{References}

1. Ouyang L, Shi Z, Zhao S, Wang FT, Zhou TT, Liu B, et al. Programmed cell death pathways in cancer: a review of apoptosis, autophagy and programmed necrosis. Cell Prolif. 2012 Dec;45(6):487-98. doi: 10.1111/j.1365-2184.2012.00845.x.

2. Fuchs $Y$, Steller $H$. Live to die another way: modes of programmed cell death and the signals emanating from dying cells. Nat Rev Mol Cell Biol. 2015 Jun;16(6):329-44. doi: 10.1038/nrm3999.

3. Munawar A, Ali SA, Akrem A, Betzel C. Snake venom peptides: tools of biodiscovery. Toxins (Basel). 2018 Nov 14;10(11):474. doi: 10.3390/ toxins10110474.

4. Shahbazi B, Najafabadi ZS, Goudarzi H, Sajadi M, Tahoori F, Bagheri M. Cytotoxic effects of Pseudocerastes persicus venom and its HPLC fractions on lung cancer cells. J Venom Anim Toxins Incl Trop Dis. 2019 Sep 16;25:e20190009. doi: 10.1590/1678-9199-JVATITD-2019-0009.

5. El-Aziz TM, Garcia Soares A, Stockand JD. Snake venoms in drug discovery: valuable therapeutic tools for life saving. Toxins (Basel). 2019 Sep 25;11(10):564. doi: 10.3390/toxins11100564.

6. Al-Asmari AK, Riyasdeen A, Al-Shahrani MH, Islam M. Snake venom causes apoptosis by increasing the reactive oxygen species in colorectal and breast cancer cell lines. Onco Targets Ther. 2016 Oct 20;9:6485-98. doi: 10.2147/OTT.S115055.

7. Bernardes-Oliveira E, Gomes DL, Palomino GM, Farias KJ, Silva WD, Rocha HA, et al. Bothrops jararaca and Bothrops erythromelas snake venoms promote cell cycle arrest and induce apoptosis via the mitochondrial depolarization of cervical cancer cells. Evid Based Complement Alternat Med. 2016;2016:1574971. doi: 10.1155/2016/1574971.

8. Sousa FC, Jorge AR, Menezes RR, Torres AF, Mello CP, Lima DB, et al. Bothrops erythromelas (Amaral, 1923) venom induces apoptosis on renal tubular epithelial cells. Toxicon. 2016;118:82-5. doi: 10.1016/j. toxicon.2016.04.040.

9. Benati RB, Costa TR, Cacemiro MD, Sampaio SV, Castro FA, Burin SM. Cytotoxic and pro-apoptotic action of MjTX-I, a phospholipase A2 isolated from Bothrops moojeni snake venom, towards leukemic cells. J Venom Anim Toxins Incl Trop Dis. 2018 Dec 20;24:40. doi: 10.1186/ s40409-018-0180-9.

10. Bezerra PH, Ferreira IM, Franceschi BT, Bianchini F, Ambrósio L, Cintra AC, et al. BthTX-I from Bothrops jararacussu induces apoptosis in human breast cancer cell lines and decreases cancer stem cell subpopulation. J Venom Anim Toxins Incl Trop Dis. 2019 Jul 29;25:e20190010. doi: 10.1590/1678-9199-JVATITD-2019-0010.

11. Akef H, Kotb N, Abo-Elmatty D, Salem S. Anti-proliferative effects of Androctonus amoreuxi scorpion and Cerastes cerastes snake venoms on human prostate cancer cells. J Cancer Prev. 2017 Mar;22(1):40-6. doi: 10.15430/JCP.2017.22.1.40.

12. Mahmoud GH, Saber SA, El-Fiky AA, Mohamed AF. In vitro evaluation of anticancer potential of Echispyramidum venom (Viperidae) and related genetic and apoptotic profile alterations. Egypt J Hosp Med. 2019;76(4):3891-900. doi: 10.12816/EJHM.2019.41567.

13. Stransky S, Costal-Oliveira F, Lopes-de-Souza L, Guerra-Duarte C, Chávez-Olórtegui C, Braga VM. In vitro assessment of cytotoxic activities of Lachesis muta muta snake venom. PLoS Negl Trop Dis. 2018 Apr 16;12(4):e0006427. doi: 10.1371/journal.pntd.0006427.

14. Kerkkamp H, Bagowski C, Kool J, van Soolingen B, Vonk FJ, Vlecken D. Whole snake venoms: cytotoxic, anti-metastatic and antiangiogenic properties. Toxicon. 2018 Aug;150:39-49. doi: 10.1016/j.toxicon.2018.05.004.

15. Ebrahim K, Vatanpour H, Zare A, Shirazi FH, Nakhjavani M. Anticancer activity a of caspian cobra (Naja naja oxiana) snake venom in human cancer cell lines via induction of apoptosis. Iran J Pharm Res. 2016 Winter;15(Suppl):101-12.

16. Antolikova NR, Kello M, Zigova M, Tischlerova $\bigvee$, Petrilla $\bigvee$, Pirnik Z, et al. Naja ashei venom induces mitochondria-mediated apoptosis in human colorectal cancer cells. Acta Biochim Pol. 2019 Jun 7;66(2):207-13. doi: 10.18388/abp.2018_2779.

17. Badr G, Sayed D, Maximous D, Mohamed AO, Gul M. Increased susceptibility to apoptosis and growth arrest of human breast cancer cells treated by a snake venom-loaded silica nanoparticles. Cell Physiol Biochem. 2014;34(5):1640-51. doi: 10.1159/000366366.
18. Machado AR, Aissa AF, Ribeiro DL, Hernandes LC, Machado CS, Bianchi $M L$, et al. The toxin BjussuLAAO-Il induces oxidative stress and DNA damage, upregulates the inflammatory cytokine genes TNF and IL6, and downregulates the apoptotic-related genes BAX, BCL2 and RELA in human Caco-2 cells. Int J Biol Macromol. 2018 Apr 1;109:212-9. doi: 10.1016/j.jjbiomac.2017.12.015.

19. Tan KK, Bay BH, Gopalakrishnakone P. L-amino acid oxidase from snake venom and its anticancer potential. Toxicon. 2018 Mar 15;144:7-13. doi: 10.1016/j.toxicon.2018.01.015.

20. Costa TR, Menaldo DL, Zoccal KF, Burin SM, Aissa AF, Castro FA, et al. CR-LAAO, an L-amino acid oxidase from Calloselasma rhodostoma venom, as a potential tool for developing novel immunotherapeutic strategies against cancer. Sci Rep. 2017 Feb 16;7:42673. doi: 10.1038/ srep42673.

21. Bonilla-Porras AR, Vargas LJ, Jimenez-Del-Rio M, Nuñez V, Velez-Pardo C. Purification of nasulysin-1: a new toxin from Porthidium nasutum snake venom that specifically induces apoptosis in leukemia cell model through caspase-3 and apoptosis-inducing factor activation. Toxicon. $2016 \mathrm{Sep}$ 15;120:166-74. doi: 10.1016/j.toxicon.2016.08.006.

22. Klein A, Capitanio JS, Maria DA, Ruiz IR. Gene expression in SK-Mel-28 human melanoma cells treated with the snake venom jararhagin. Toxicon. 2011 Jan;57(1):1-8. doi: 10.1016/j.toxicon.2010.09.001.

23. Ben-Mabrouk H, Zouari-Kessentini R, Montassar F, Koubaa ZA, Messaadi E, Guillonneau X, et al. CC5 and CC8, two homologous disintegrins from Cerastes cerastes venom, inhibit in vitro and ex vivo angiogenesis. Int J Biol Macromol. 2016 May;86:670-80. doi: 10.1016/j.ijbiomac.2016.02.008.

24. Hammouda MB, Montenegro MF, Sánchez-Del-Campo L, Zakraoui O, Aloui Z, Riahi-Chebbi I, et al. Lebein, a snake venom disintegrin, Induces apoptosis in human melanoma cells. Toxins (Basel). 2016 Jul 5;8(7):206. doi: $10.3390 /$ toxins 8070206 .

25. Jiménez-Charris E, Lopes DS, Gimenes SN, Teixeira SC, MontealegreSánchez L, Solano-Redondo L, et al. Antitumor potential of Pllans-II, an acidic Asp49-PLA2 from Porthidium lansbergii lansbergii snake venom on human cervical carcinoma HeLa cells. Int J Biol Macromol. 2019 Feb 1;122:1053-61. doi: 10.1016/j.ijbiomac.2018.09.053.

26. Merkel P, Beck A, Muhammad K, Ali SA, Schönfeld C, Voelter W, et al. Spermine isolated and identified as the major trypanocidal compound from the snake venom of Eristocophis macmahoni causes autophagy in Trypanosoma brucei. Toxicon. 2007 Sep 15;50(4):457-69. doi: 10.1016/j. toxicon.2007.04.022.

27. Liu Y, Ming W, Wang Y, Liu S, Qiu Y, Xiang Y, et al. Cytotoxin 1 from Naja atra Cantor venom induced necroptosis of leukemia cells. Toxicon. 2019 Jul;165:110-115. doi: 10.1016/j.toxicon.2019.04.012.

28. Palm NW, Medzhitov R. Role of the inflammasome in defense against venoms. Proc Natl Acad Sci U S A. 2013 Jan 29;110(5):1809-14. doi: 10.1073/pnas.1221476110.

29. Steinmann GG. Changes in the human thymus during aging. Curr Top Pathol. 1986;75:43-88. doi: 10.1007/978-3-642-82480-7_2.

30. Palmer DB. The effect of age on thymic function. Front Immunol. 2013 Oct 7;4:316. doi: 10.3389/fimmu.2013.00316.

31. Bertho JM, Demarquay C, Moulian N, van der Meeren A, Berrih-Aknin $S$, Gourmelon P. Phenotypic and immunohistological analyses of the human adult thymus: evidence for an active thymus during adult life. Cell Immunol. 1997 Jul 10;179(1):30-40. doi: 10.1006/cimm.1997.1148.

32. Falci C, Gianesin K, Sergi G, Giunco S, Ronch I, Valpione S, et al. Immune senescence and cancer in elderly patients: results from an exploratory study. Exp Gerontol. 2013 Dec;48(12):1436-42. doi: 10.1016/j.exger.2013.09.011.

33. Fletcher AL, Calder A, Hince MN, Boyd RL, Chidgey AP. The contribution of thymic stromal abnormalities to autoimmune disease. Crit Rev Immunol. 2011;31(3):171-87. doi: 10.1615/critrevimmunol.v31.i3.10.

34. Dion ML, Poulin JF, Bordi R, Sylvestre M, Corsini R, Kettaf N, et al. HIV infection rapidly induces and maintains a substantial suppression of thymocyte proliferation. Immunity. 2004 Dec;21(6):757-68. doi: 10.1016/j. immuni.2004.

35. Lynch HE, Goldberg GL, Chidgey A, van den Brink MR, Boyd R, Sempowski GD. Thymic involution and immune reconstitution. Trends Immunol. 2009 Jul;30(7):366-73. doi: 10.1016/j.it.2009.04.003. 
36. Benjamin CL, Stowe RP, John L St, Sams CF, Mehta SK, Crucian BE, et al. Decreases in thymopoiesis of astronauts returning from space flight. $\mathrm{JCl}$ Insight. 2016 Aug 4;1(12):e88787. doi: 10.1172/jci.insight.88787.

37. Rytter MJ, Kolte L, Briend A, Friis H, Christensen VB. The immune system in children with malnutrition: a systematic review. PLoS One. 2014 Aug 25;9(8):e105017. doi: 10.1371/journal.pone.0105017.

38. Savino W. The thymus is a common target organ in infectious diseases. PLoS Pathog. 2006;2(6):e62. doi: 10.1371/journal.ppat.0020062.

39. Harvey AL, Karlsson E. Dendrotoxin from the venom of the green mamba, Dendroaspis angusticeps. A neurotoxin that enhances acetylcholine release at neuromuscular junction. Naunyn Schmiedebergs Arch Pharmacol. 1980 May;312(1):1-6. doi: 10.1007/BF00502565.

40. Poorheidari $\mathrm{G}$. Isolation of a postynaptic blocker from the venom of the green mamba, Dendroaspis angusticeps. Iran Biomed J. 1999 Apr;3(1-2):53-7.

41. Huang TF, Peng HC, Peng IS, Teng CM, Ouyang C. An antiplatelet peptide, gabonin, from Bitis gabonica snake venom. Arch Biochem Biophys. 1992 Oct;298(1):13-20. doi: 10.1016/0003-9861(92)90087-d.

42. Lomonte B, Tsai WC, Ureña-Diaz JM, Sanz L, Mora-Obando D, Sánchez $E E$, et al. Venomics of new world pit vipers: genus-wide comparisons of venom proteomes across agkistrodon. J Proteomics. 2014 Jan 16;96:10316. doi: 10.1016/j.jprot.2013.10.036.

43. Lauridsen LP, Laustsen AH, Lomonte B, Gutiérrez JM. Toxicovenomics and antivenom profiling of the eastern green mamba snake (Dendroaspis angusticeps). J Proteomics. 2016 Mar 16;136:248-61. doi: 10.1016/j. jprot.2016.02.003.

44. Boda F, Banfai K, Garai K, Curticapean A, Berta L, Sipos E, et al. Effect of Vipera ammodytes ammodytes snake venom on the human cytokine network. Toxins (Basel). 2018 Jun 25;10(7):259. doi: 10.3390/ toxins10070259.

45. Mackessy S. The field of reptile toxinology. In: Mackessy SP, editor. Handbook of venoms and toxins of reptiles. Boca Raton: Taylor \& Francis; 2009. p. 3-24.

46. Petras D, Heiss P, Harrison RA, Süssmuth RD, Calvete JJ. Top-down venomics of the East African green mamba, Dendroaspis angusticeps, and the black mamba, Dendroaspis polylepis, highlight the complexity of their toxin arsenals. J Proteomics. 2016 Sep 2;146:148-64. doi: 10.1016/j. jprot.2016.06.018.

47. Conlon JM, Prajeep M, Mechkarska M, Arafat K, Attoub S, Adem A, et al. Peptides with in vitro anti-tumor activity from the venom of the eastern green mamba, Dendroaspis angusticeps (Elapidae). J Venom Res. 2014 Jun 19;5:16-21.

48. Calvete JJ, Marcinkiewicz C, Sanz L. Snake venomics of Bitis gabonica gabonica. Protein family composition, subunit organization of venom toxins, and characterization of dimeric disintegrins bitisgabonin-1 and bitisgabonin-2. J Proteome Res. 2007 Jan;6(1):326-36. doi: 10.1021/ pr060494k.

49. Calvete JJ, Escolano J, Sanz L. Snake venomics of Bitis species reveals large intragenus venom toxin composition variation: application to taxonomy of congeneric taxa. J Proteome Res. 2007 Jul;6(7):2732-45. doi: 10.1021/ pr0701714.

50. Barraud L, Merle P, Soma E, Lefrançois L, Guerret S, Chevallier M, et al. Increase of doxorubicin sensitivity by doxorubicin-loading into nanoparticles for hepatocellular carcinoma cells in vitro and in vivo. J Hepatol. 2005 May;42(5):736-43. doi: 10.1016/j.jhep.2004.12.035.

51. Wohlfert EA, Gorelik L, Mittler R, Flavell RA, Clark RB. Cutting edge: deficiency in the $\mathrm{E} 3$ ubiquitin ligase $\mathrm{Cbl}-\mathrm{b}$ results in a multifunctional defect in T cell TGF-beta sensitivity in vitro and in vivo. J Immunol. 2006 Feb 1;176(3):1316-20. doi: 10.4049/jimmunol.176.3.1316.

52. Elmore S. Apoptosis: a review of programmed cell death. Toxicol Pathol. 2007 Jun 1;35(4):495-516. doi: 10.1080/01926230701320337.

53. Kiraz Y, Adan A, Kartal Yandim M, Baran Y. Major apoptotic mechanisms and genes involved in apoptosis. Tumour Biol. 2016 Jul;37(7):8471-86. doi: 10.1007/s13277-016-5035-9.

54. Su Z, Yang Z, Xu Y, Chen Y, Yu Q. Apoptosis, autophagy, necroptosis, and cancer metastasis. Mol Cancer. 2015 Feb 21;14:48. doi: 10.1186/ s12943-015-0321-5.
55. Nagata S. Apoptosis and autoimmune diseases. Ann N Y Acad Sci. 2010 Oct;1209:10-6. doi: 10.1111/j.1749-6632.2010.05749.x.

56. Weinlich R, Oberst A, Beere HM, Green DR. Necroptosis in development, inflammation and disease. Nat Rev Mol Cell Biol. 2017 Feb;18(2):127-136. doi: 10.1038/nrm.2016.149.

57. Ghavami S, Shojaei S, Yeganeh B, Ande SR, Jangamreddy JR, Mehrpour M, et al. Autophagy and apoptosis dysfunction in neurodegenerative disorders. Prog Neurobiol. 2014 Jan;112:24-49. doi: 10.1016/j.pneurobio.2013.10.004.

58. Julien O, Wells JA. Caspases and their substrates. Cell Death Differ. 2017 Aug;24(8):1380-9. doi: 10.1038/cdd.2017.44.

59. Zhou M, Li Y, Hu Q, Bai XC, Huang W, Yan C, et al. Atomic structure of the apoptosome: mechanism of cytochrome c- and dATP-mediated activation of Apaf-1. Genes Dev. 2015 Nov 15;29(22):2349-61. doi: 10.1101/ gad. 272278.115

60. Jorgensen I, Rayamajhi M, Miao EA. Programmed cell death as a defence against infection. Nat Rev Immunol. 2017 Mar;17(3):151-64. doi: 10.1038/ nri.2016.147.

61. Wiley SR, Schooley K, Smolak PJ, Din WS, Huang CP, Nicholl JK, et al. Identification and characterization of a new member of the TNF family that induces apoptosis. Immunity. $1995 \mathrm{Dec} ; 3(6): 673-82$. doi: 10.1016/1074-7613(95)90057-8.

62. Ralff MD, El-Deiry WS. TRAIL pathway targeting therapeutics. Expert Rev Precis Med Drug Dev. 2018;3(3):197-204. doi: 10.1080/23808993.2018.1476062.

63. Sayers TJ. Targeting the extrinsic apoptosis signaling pathway for cancer therapy. Cancer Immunol Immunother. 2011 Aug;60(8):1173-80. doi: 10.1007/s00262-011-1008-4.

64. Chen $M$, Wang J. Initiator caspases in apoptosis signaling pathways. Apoptosis. 2002 Aug;7(4):313-9. doi: 10.1023/a:1016167228059.

65. He C, Klionsky DJ. Regulation mechanisms and signaling pathways of autophagy. Annu Rev Genet. 2009;43:67-93. doi: 10.1146/annurevgenet-102808-114910.

66. Kundu M, Thompson CB. Autophagy: basic principles and relevance to disease. Annu Rev Pathol. 2008;3:427-55. doi: 10.1146/annurev. pathmechdis.2.010506.091842.

67. Eisenberg-Lerner A, Bialik S, Simon HU, Kimchi A. Life and death partners: apoptosis, autophagy and the cross-talk between them. Cell Death Differ. 2009 Jul;16(7):966-75. doi: 10.1038/cdd.2009.33

68. Wu W, Liu P, Li J. Necroptosis: an emerging form of programmed cell death. Crit Rev Oncol Hematol. 2012 Jun;82(3):249-58. doi: 10.1016/j. critrevonc.2011.08.004.

69. Vanden Berghe T, Linkermann A, Jouan-Lanhouet S, Walczak $H$, Vandenabeele P. Regulated necrosis: the expanding network of nonapoptotic cell death pathways. Nat Rev Mol Cell Biol. 2014 Feb;15:135-47. doi: $10.1038 / \mathrm{nrm} 3737$.

70. Galluzzi L, Kepp O, Krautwald S, Kroemer G, Linkermann A. Molecular mechanisms of regulated necrosis. Semin Cell Dev Biol. 2014 Nov;35:2432. doi: 10.1016/j.semcdb.2014.02.006.

71. Fatokun AA, Dawson VL, Dawson TM. Parthanatos: mitochondriallinked mechanisms and therapeutic opportunities. Br J Pharmacol. 2014 Apr;171(8):2000-16. doi: 10.1111/bph.12416.

72. Wang Y, Kim NS, Haince JF, Kang HC, David KK, Andrabi SA, et al. Poly(ADP-ribose) (PAR) binding to apoptosis-inducing factor is critical for PAR polymerase-1-dependent cell death (parthanatos). Sci Signal. 2011 Apr 5;4(167):ra20. doi: 10.1126/scisignal.2000902.

73. Xie Y, Hou W, Song X, Yu Y, Huang J, Sun X, et al. Ferroptosis: process and function. Cell Death Differ. 2016 Mar;23(3):369-79. doi: 10.1038/ cdd.2015.158.

74. Walle LV, Lamkanfi M. Pyroptosis. Curr Biol. 2016 Jul 11;26(13):R568-72. doi: 10.1016/j.cub.2016.02.019.

75. Willingham SB, Bergstralh DT, O'Connor W, Morrison AC, Taxman DJ, Duncan JA, et al. Microbial pathogen-induced necrotic cell death mediated by the inflammasome components CIAS1/Cryopyrin/NLRP3 and ASC. Cell Host Microbe. 2007 Sep 13;2(3):147-59. doi: 10.1016/j.chom.2007.07.009.

76. Tonnus W, Linkermann A. Regulated Necrosis and Its Immunogenicity. In: Rich RR, Fleisher TA, Shearer WT, Schroeder HW, Frew AJ, Weyand CM, 
editors. Clinical Immunology: principles and practice. 5th ed. Amsterdam: Elsevier; 2019. p. 197-205.e1. doi: 10.1016/B978-0-7020-6896-6.00013-2.

77. Kim-Campbell N, Gomez H, Bayir H. Cell death pathways: apoptosis and regulated necrosis. In: Ronco C, Bellomo R, Kellum JA, Ricci Z, editors. Critical care nephrology. 3rd ed. Philadelphia: Elsevier; 2019. p. 113-121. e2. doi: 10.1016/B978-0-323-44942-7.00020-0.

78. Man SM, Karki R, Kanneganti TD. Molecular mechanisms and functions of pyroptosis, inflammatory caspases and inflammasomes in infectious diseases. Immunol Rev. 2017 May;277(1):61-75. doi: 10.1111/imr.12534.

79. Shi J, Gao W, Shao F. Pyroptosis: gasdermin-mediated programmed necrotic cell death. Trends Biochem Sci. 2017 Apr;42(4):245-54. doi: 10.1016/j.tibs.2016.10.004.

80. Liu L, Sun B. Neutrophil pyroptosis: new perspectives on sepsis. Cell Mol Life Sci. 2019 Jun;76(11):2031-42. doi: 10.1007/s00018-019-03060-1.

81. Vasconcelos NM, van Opdenbosch N, van Gorp H, Parthoens E, Lamkanfi M. Single-cell analysis of pyroptosis dynamics reveals conserved GSDMDmediated subcellular events that precede plasma membrane rupture. Cell Death Differ. 2019;26:146-61. doi: 10.1038/s41418-018-0106-7.

82. Wang M, Jiang S, Zhang Y, Li P, Wang K. The multifaceted roles of pyroptotic cell death pathways in cancer. Cancers (Basel). 2019 Sep;11(9):1313. doi: 10.3390/cancers11091313.

83. Kelley N, Jeltema D, Duan Y, He Y. The NLRP3 Inflammasome: an overview of mechanisms of activation and regulation. Int J Mol Sci. 2019 Jul 6;20(13):3328. doi: 10.3390/ijms20133328.

84. Youm YH, Kanneganti TD, Vandanmagsar B, Zhu X, Ravussin A, Adijiang $A$, et al. The Nlrp3 inflammasome promotes age-related thymic demise and immunosenescence. Cell Rep. 2012 Jan 26;1(1):56-68. doi: 10.1016/j. celrep.2011.11.005.

85. Alves RM, Antonucci GA, Paiva HH, Cintra AC, Franco JJ, MendonçaFranqueiro EP, et al. Evidence of caspase-mediated apoptosis induced by I-amino acid oxidase isolated from Bothrops atrox snake venom. Comp Biochem Physiol A Mol Integr Physiol. 2008 Dec;151(4):542-50. doi: 10.1016/j.cbpa.2008.07.007.

86. Santos WG, Silveira TL, Fiúza AT, Botelho AF, Gonçalves IN, Ferreira E, et al. Bothrops alternatus snake venom induces apoptosis of skeletal muscle cells in a rabbit model. Arq Bras Med Vet Zootec. 2019 Feb;71(1):349-52. doi: 10.1590/1678-4162-10105.

87. Tavares C, Maciel T, Burin S, Ambrósio L, Ghisla S, Sampaio S, et al. L-Amino acid oxidase isolated from Calloselasma rhodostoma snake venom induces cytotoxicity and apoptosis in JAK2V617F-positive cell lines. Rev Bras Hematol Hemoter. 2016 Jun;38(2):128-34. doi: 10.1016/j. bjhh.2016.03.004.

88. Costal-Oliveira F, Stransky S, Guerra-Duarte C, Souza DL, Vivas-Ruiz DE, Yarlequé A, et al. L-amino acid oxidase from Bothrops atrox snake venom triggers autophagy, apoptosis and necrosis in normal human keratinocytes. Sci Rep. 2019 Jan 28;9:781. doi: 10.1038/s41598-018-37435-4.

89. Ceremuga M, Stela M, Janik E, Gorniak L, Synowiec E, Sliwinski T, et al. Melittin: a natural peptide from bee venom which induces apoptosis in human leukaemia cells. Biomolecules. 2020 Feb 6;10(2):247. doi: 10.3390/ biom10020247.

90. Boeno CN, Paloschi MV, Lopes JA, Pires WL, Setúbal SD, Evangelista $J R$, et al. Inflammasome activation induced by a snake venom Lys49phospholipase A2 homologue. Toxins (Basel). 2019 Dec 31;12(1):22. doi: 10.3390/toxins12010022.

91. Cedro RC, Menaldo DL, Costa TR, Zoccal KF, Sartim MA, Santos-Filho $\mathrm{NA}$, et al. Cytotoxic and inflammatory potential of a phospholipase A2 from Bothrops jararaca snake venom. J Venom Anim Toxins Incl Trop Dis. 2018 Nov 23;24:33. doi: 10.1186/s40409-018-0170-y.

92. Zoccal KF, Sorgi CA, Hori Jl, Paula-Silva FWG, Arantes EC, Serezani CH, et al. Opposing roles of LTB4 and PGE2 in regulating the inflammasomedependent scorpion venom-induced mortality. Nat Commun. $2016 \mathrm{Feb}$ 23;7:10760. doi: 10.1038/ncomms10760.

93. Lee KH, Kang TB. The Molecular Links between Cell Death and Inflammasome. Cells. 2019 Sep 10;8(9):1057. doi: 10.3390/cells8091057.

94. Galluzzi L, Vitale I, Aaronson SA, Abrams JM, Adam D, Agostinis P, et al. Molecular mechanisms of cell death: recommendations of the
Nomenclature Committee on Cell Death 2018. Cell Death Differ. 2018 Mar;25(3):486-541. doi: 10.1038/s41418-017-0012-4.

95. Horn S, Hughes MA, Schilling R, Sticht C, Tenev T, Ploesser M, et al. Caspase-10 negatively regulates Caspase-8-Mediated cell death, switching the response to CD95L in favor of NF-KB activation and cell survival. Cell Rep. 2017 Apr 25;19(4):785-97. doi: 10.1016/j.celrep.2017.04.010.

96. Sun SY, Yue P, Zhou JY, Wang Y, Kim HR, Lotan R, Wu GS. Overexpression of BCL2 blocks TNF-related apoptosis-inducing ligand (TRAIL)-induced apoptosis in human lung cancer cells. Biochem Biophys Res Commun. 2001 Jan 26;280(3):788-97. doi: 10.1006/bbrc.2000.4218.

97. Karin M, Lin A. NF-kappaB at the crossroads of life and death. Nat Immunol. 2002 Mar;3(3):221-7. doi: 10.1038/ni0302-221.

98. Srinivasula SM, Ashwell JD. IAPs: what's in a name? Mol Cell. 2008 Apr 25;30(2):123-35. doi: 10.1016/j.molcel.2008.03.008.

99. Katagiri N, Shobuike T, Chang B, Kukita A, Miyamoto H. The human apoptosis inhibitor NAIP induces pyroptosis in macrophages infected with Legionella pneumophila. Microbes Infect. 2012 Nov;14(13):1123-32. doi: 10.1016/j.micinf.2012.03.006.

100. Simon P, Sargent R, Rabson A. Inhibitor of apoptosis protein BIRC3 (API2, cIAP2, AIP1) is upregulated by the non-canonical NFKB pathway. Cancer Res. 2007 May;67(9):5327.

101. Lippens S, Kockx M, Knaapen M, Mortier L, Polakowska R, Verheyen $A$, et al. Epidermal differentiation does not involve the pro-apoptotic executioner caspases, but is associated with caspase-14 induction and processing. Cell Death Differ. 2000 Dec;7(12):1218-24. doi: 10.1038/ sj.cdd. 4400785.

102. Lippens S, VandenBroecke C, van Damme E, Tschachler E, Vandenabeele P, Declercq W. Caspase-14 is expressed in the epidermis, the choroid plexus, the retinal pigment epithelium and thymic Hassall's bodies. Cell Death Differ. 2003 Feb;10(2):257-9. doi: 10.1038/sj.cdd.4401141.

103. Lachner J, Mlitz V, Tschachler E, Eckhart L. Epidermal cornification is preceded by the expression of a keratinocyte-specific set of pyroptosisrelated genes. Sci Rep. 2017 Dec 12;7(1):17446. doi: 10.1038/s41598017-17782-4 6.

104. Mikušová R, Meštanová V, Polák Š, Varga I. What do we know about the structure of human thymic Hassall's corpuscles? A histochemical, immunohistochemical, and electron microscopic study. Ann Anat. 2017 May;211:140-8. doi: 10.1016/j.aanat.2017.02.006.

105. Jain N, Sudhakar C, Swarup G. Tumor necrosis factor-a-induced caspase-1 gene expression. Role of p73. FEBS J. 2007 Sep;274(17):4396-407. doi: 10.1111/j.1742-4658.2007.05969.x.

106. Furuoka M, Ozaki KI, Sadatomi D, Mamiya S, Yonezawa T, Tanimura S, et al. TNF-a induces caspase-1 activation independently of simultaneously induced NLRP3 in 3T3-L1 cells. J Cell Physiol. 2016 Dec;231(12):2761-7. doi: $10.1002 /$ jcp. 25385 .

107. Álvarez S, Muñoz-Fernández MÁ. TNF-A may mediate inflammasome activation in the absence of bacterial infection in more than one way. PLoS One. 2013 Aug 7;8(8):e71477. doi: 10.1371/journal.pone.0071477.

108. Pan G, Bauer JH, Haridas $\vee$, Wang S, Liu D, Yu G, et al. Identification and functional characterization of DR6, a novel death domain-containing TNF receptor. FEBS Lett. 1998 Jul 24;431(3):351-6. doi: 10.1016/s00145793(98)00791-1.

109. Campo ML. Apoptosis. In: Salido GM, Rosado JA, editors. Apoptosis: involvement of oxidative stress and intracellular $\mathrm{Ca} 2+$ homeostasi. Dordrecht: Springer Netherlands; 2009. p. 17-55. doi: 10.1007/978-14020-9873-4_2.

110. Etemadi N, Holien JK, Chau D, Dewson G, Murphy JM, Alexander WS, et al. Lymphotoxin a induces apoptosis, necroptosis and inflammatory signals with the same potency as tumour necrosis factor. FEBS J. 2013 Nov;280(21):5283-97. doi: 10.1111/febs.12419.

111. Müller JR, Siebenlist U. Lymphotoxin beta receptor induces sequential activation of distinct NF-kappa B factors via separate signaling pathways. J Biol Chem. 2003 Apr 4;278(14):12006-12. doi: 10.1074/jbc.M210768200.

112. Ganeff C, Remouchamps C, Boutaffala L, Benezech C, Galopin G, Vandepaer $S$, et al. Induction of the alternative NF-KB pathway by lymphotoxin a $\beta(\mathrm{LTa} \beta)$ relies on internalization of LT $\beta$ receptor. Mol Cell Biol. 2011 Nov;31(21):4319-34. doi: 10.1128/MCB.05033-11. 
113. Liu WH, Chang LS. Suppression of ADAM17-mediated Lyn/Akt pathways induces apoptosis of human leukemia $U 937$ cells: Bungarus multicinctus protease inhibitor-like protein-1 uncovers the cytotoxic mechanism. J Biol Chem. 2010 Oct 1;285(40):30506-15. doi: 10.1074/jbc.M110.156257.

114. Renner F, Schmitz ML. Autoregulatory feedback loops terminating the NF-kappaB response. Trends Biochem Sci. 2009 Mar;34(3):128-35. doi: 10.1016/j.tibs.2008.12.003.

115. Park MH, Jo M, Won D, Song HS, Song MJ, Hong JT. Snake venom toxin from Vipera lebetina turanica sensitizes cancer cells to TRAIL through ROS- and JNK-mediated upregulation of death receptors and downregulation of survival proteins. Apoptosis. 2012 Dec;17(12):1316-26. doi: 10.1007/s10495-012-0759-5.

116. Tasoulis T, Isbister GK. A review and database of snake venom proteomes. Toxins (Basel). 2017 Sep 18;9(9):290. doi: 10.3390/toxins9090290.

117. el Hakim AE, Gamal-Eldeen AM, Shahein YE, Mansour NM, Wahby AF, Abouelella AM. Purification and characterization of a cytotoxic neurotoxinlike protein from Naja haje haje venom that induces mitochondrial apoptosis pathway. Arch Toxicol. 2011 Aug;85(8):941-52. doi: 10.1007/ s00204-010-0631-8.
118. Bedoya-Medina J, Mendivil-Perez M, Rey-Suarez P, Jimenez-Del-Rio $M$, Núñez $\vee$, Velez-Pardo C. L-amino acid oxidase isolated from Micrurus mipartitus snake venom (MipLAAO) specifically induces apoptosis in acute lymphoblastic leukemia cells mostly via oxidative stress-dependent signaling mechanism. Int J Biol Macromol. 2019 Aug 1;134:1052-62. doi: 10.1016/j.ijbiomac.2019.05.

119. Fakhri A, Omranipour R, Fakhri S, Mirshamsi M, Zangeneh F, Vatanpour $\mathrm{H}$, et al. Naja naja oxiana venom fraction selectively induces rosmediated apoptosis in human colorectal tumor cells by directly targeting mitochondria. Asian Pac J Cancer Prev. 2017 Aug 27;18(8):2201-8. doi: 10.22034/APJCP.2017.18.8.2201.

120. Park HH. Caspase recruitment domains for protein interactions in cellular signaling (Review). Int J Mol Med. 2019 Mar;43(3):1119-27. doi: 10.3892/ ijmm.2019.4060.

121. ParkJH, Choi JY, Mustafa MF, Park HH. In vitro reconstitution of interactions in the CARD9 signalosome. Mol Med Rep. 2017 Oct;16(4):3910-6. doi: 10.3892/mmr.2017.7116

122. Kao WP, Yang CY, Su TW, Wang YT, Lo YC, Lin SC. The versatile roles of CARDs in regulating apoptosis, inflammation, and NF-KB signaling. Apoptosis. 2015 Feb;20(2):174-95. doi: 10.1007/s10495-014-1062-4. 